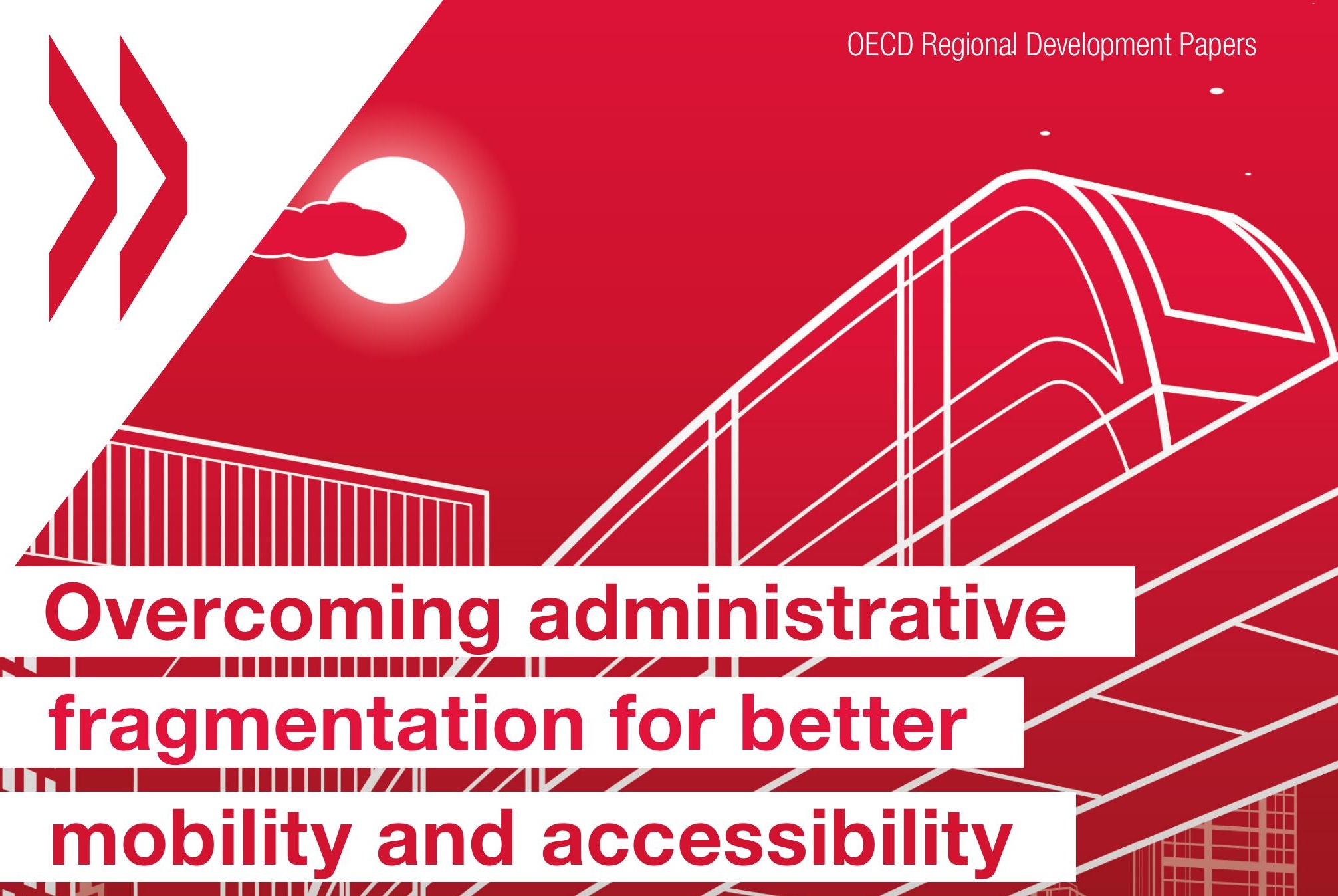
卌i IIT The case of the Madrid Autonomous Community (n)

\title{
(-) J)ECD
}


OECD Regional Development Papers

\title{
Overcoming administrative fragmentation for better mobility and accessibility
}

\section{The case of the Madrid Autonomous Community}

By: Oscar Huerta Melchor and Antonio Cañamás Catalá

\begin{abstract}
Overcoming administrative fragmentation to build an integrated public transport network is one of the main actions taken in the Madrid Region to improve mobility. The lack of a regional development plan and the poor linkages between transport and urban development policies are, however, the main obstacles to fostering accessibility. The paper argues that a regional development plan and spatial planning to underpin transport investment decisions are needed to make the most of transport infrastructure and foster growth, well-being and effective environmental policies. This paper aims to reveal policy lessons from the experience of the Madrid Region in fostering urban mobility and accessibility, which could inspire policy change in other EU cities.
\end{abstract}

JEL codes: H70, R0, R40, R420, R52, R58, R520

Keywords: Urban accessibility, transport, mobility, transport planning

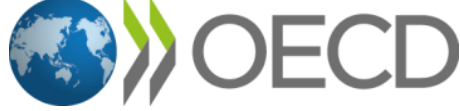




\section{ABOUT THE OECD}

The OECD is a multi-disciplinary inter-governmental organisation of 37 member countries which engages in its work an increasing number of non-members from all regions of the world. The Organisation's core mission today is to help governments work together towards a stronger, cleaner, fairer global economy. Through its network of 250 specialised committees and working groups, the OECD provides a setting where governments compare policy experiences, seek answers to common problems, identify good practices, and co-ordinate domestic and international policies. More information available: www.oecd.org.

\section{ABOUT OECD REGIONAL DEVELOPMENT WORKING PAPERS}

Papers from the Centre for Entrepreneurship, SMEs, Regions and Cities of the OECD cover a full range of topics including regional statistics and analysis, urban governance and economics, rural governance and economics, and multi-level governance. Depending on the programme of work, the papers can cover specific topics such as regional innovation and networks, sustainable development, the determinants of regional growth or fiscal consolidation at the subnational level. OECD Regional Development Papers are published on http://www.oecd.org/cfe/regional-policy.

This paper is published under the responsibility of the Working Party on Urban Policy (WPURB) of the OECD Regional Development Policy Committee (RDPC) on 7 December 2020 under the cote [CFE/RDPC/URB(2020)22]. The opinions expressed and the arguments employed herein do not necessarily reflect the official views of OECD member countries.

This paper is authorised for publication by Lamia Kamal-Chaoui, Director, Centre for Entrepreneurship, SMEs, Regions and Cities, OECD.

This document, as well as any statistical data and map included herein, are without prejudice to the status of or sovereignty over any territory, to the delimitation of international frontiers and boundaries and to the name of any territory, city or area.

This publication was produced with the financial support of the European Union. Its contents are the sole responsibility of Oscar Huerta Melchor and Antonio Cañamás Catalá and do not necessarily reflect the views of the European Union.

\section{(C) OECD 2020}

You can copy, download or print OECD content for your own use, and you can include excerpts from OECD publications, databases and multimedia products in your own documents, presentations, blogs, websites and teaching materials, provided that suitable acknowledgement of OECD as source and copyright owner is given. All requests for public or commercial use and translation rights should be submitted to rights@oecd.org. 


\section{Acknowledgements}

This policy paper was produced by the OECD Centre for Entrepreneurship, SMEs, Regions and Cities (CFE) led by Lamia Kamal-Chaoui, Director. It is part of the Programme of Work of the OECD's Regional Development Policy Committee (RDPC) and its Working Party on Urban Policy.

The policy paper was prepared as part of a wider project on Rethinking urban and regional transport needs: improving access, safety and well-being through transport investment and policies, jointly implemented by the CFE and the OECD's International Transport Forum (ITF). The financial contributions from the Directorate-General for Regional and Urban Policy of the European Commission and the support and feedback received at various stages of the project by Lewis Dijkstra are gratefully acknowledged.

The OECD Secretariat would like to thank the numerous local officials and experts that met with the OECD team and provided valuable insights in Madrid. In particular, the OECD Secretariat is grateful to Laura Delgado Hernández and Francisco Javier Gómez López from the Consorcio Regional de Transportes de Madrid (CRTM) for their kind assistance in organising the study mission and providing valuable information for the case study.

The policy paper was drafted by Oscar Huerta Melchor, Policy Analyst in the Cities, Urban Policies and Sustainable Development Division, CFE, with the support and inputs from Antonio Cañamás Catalá, at the time Policy Analyst in the Cities, Urban Policies and Sustainable Development Division, CFE. Alexander C. Lembcke coordinated the overall project under the supervision of Rudiger Ahrend, Head of the Economic Analysis, Statistics and Multi-level Governance section in CFE. The working paper was reviewed and commented by Stephen Perkins and his team at the OECD International Transport Forum. The policy paper benefitted from comments from Soo-Jin Kim, and Andrew Lombardi from the Cities, Urban Policies and Sustainable Development Division, CFE.

This policy paper was submitted to delegates for approval by written procedure by 7 December 2020 under the cote [CFE/RDPC/URB(2020)22]. Andrew Brenner edited the final version, and Pilar Philip prepared the manuscript for publication. 


\section{Table of contents}

Acknowledgements 3

Executive Summary $\quad 6$

1 Introduction $\quad 9$

2 Institutional framework for regional transport policies $\quad 11$

Socioeconomic overview of the Madrid Region 11

A public transport authority for the entire region 13

Financing of the public transport system $\quad 15$

3 Regional development and transport planning instruments $\quad 17$

Lack of a formal regional development strategy 17

The Strategic Sustainable Mobility Plan for the Madrid Region $\quad 17$

Municipal Sustainable Urban Mobility Plans $\quad 20$

4 The metropolitan public transport network 23

The CAM has a vast public transport network 23

The CAM has a modern rail transport network 24

A mix of public and private operators provide bus services in the region $\quad 25$

Intermodal points facilitate transfer to higher capacity modes of transport $\quad 26$

5 The state of mobility in the Madrid region $\quad 27$

Private car travel remains the main mode of transport $\quad 27$

Most CAM residents are homeowners thus increasing demand for public transport $\quad 29$

Smart city and mobility solutions are used to promote sustainable transport 30

The city of Madrid is a lab for an innovative mobility regulation 32

The 2009 financial crisis blocked transport projects in the CAM 33

6 From mobility to urban accessibility 34

Shifting from promoting mobility to urban accessibility in the CAM 34

Options to improve the efficiency of public transport in the CAM 35

In conclusion - What lessons can be learned from the CAM's mobility initiatives? $\quad 40$

References $\quad 43$ 


\section{FIGURES}

Figure 1. Urban segregation in selected European urban areas

Figure 2. Evolution of the institutional framework for public transport in the CAM 13

Figure 3. CRTM special budget regime - two different budgets $\quad 15$

Figure 4. Transport planning framework for the Madrid Region $\quad 18$

Figure 5. The mobility system of the city of Madrid 21

Figure 6. Classification of public transport in the Madrid Region 23

Figure 7. The integrated transport network of the Madrid Region $\quad 24$

Figure 8. Modal share of total trips in the CAM 28

Figure 9. Demand for public transport services in the CAM 28

Figure 10. Most trips in the CAM are commutes to work 30

Figure 11. Policy priorities for enhancing urban accessibility in the Madrid Region 36

\section{TABLES}

Table 1. Number of jobs per zone in the CAM

Table 2. Operational framework of the CAM's public transport network 14

Table 3. Financing of the transport system in the CAM 16

Table 4. The Strategic Sustainable Mobility Plan of the CAM 2013-2025 19

Table 5. Municipal plans with an impact on mobility in the City of Madrid 22

Table 6. Distribution of mobility by spatial area in the CAM 29

Table 7. Key points of the CAM's accessibility experience 35 


\section{Executive Summary}

The Madrid Region (Comunidad Autónoma de Madrid, CAM) is the political centre of Spain and one of its main economic development hubs. It is composed of 179 municipalities, including the City of Madrid, and generates one-fourth of national GDP. Financial and insurance activity, commerce, transport and tourism are some of the main economic industries of the region. Like the rest of the country, the Madrid Region was severely affected by the 2008-09 financial crisis. Now, the COVID-19 pandemic has provoked a rethinking of behaviour patterns, as well as social and economic priorities. Policy-makers increasingly recognise that the municipalities and the region as a whole must do more to improve the quality of life for residents, overcome the longstanding socio-economic challenges exacerbated by the current COVID-19 crisis, and address the impacts of urbanisation in general.

One step in that direction is to foster greater urban accessibility in the entire region. It implies facilitating people's access to jobs, goods and services by simplifying the way they reach destinations. COVID-19 has generated a controversy about population density, as crowded areas are seen as areas where the virus can be caught more easily. However, the current crisis has highlighted the benefits of proximity as it facilitates implementing effective policy responses to control the pandemic, make better use of social infrastructure and access health services. Promoting accessibility is not just a matter of fighting the spread of the virus, but improving the quality of urbanisation to promote inclusive development, support economic recovery and enhance resiliency in the event of a similar scenario should occur. To foster urban accessibility, the CAM needs to take stock of the transport policy reforms and investments conducted over the years. Some of the most important ones include:

- The creation of the Consorcio Regional de Transportes de Madrid (CRTM) as the regional transport authority. The CRTM has been the key to unlocking the potential of the public transport sector in a highly fragmented metropolitan area. It has the technical capacity to guide and coordinate transport projects that have allowed the region to develop one of the best transport systems in the country.

- The introduction of an integrated transport system has contributed to increasing the efficiency of different transport modes, by complementing one another. The system is based on four main pillars: administrative integration (facilitated by the CRTM), a regional integrated fare system, modal integration (which refers to the complementarity of all transport modes), and technological integration for data gathering, protocols and processes between operators, customers and authorities.

- The regional Sustainable Urban Mobility Plan (SSMP), which helps coordinate the transport efforts of the different local governments in the region. The SSMP has created the public transport vision for 2025: an efficient, safe and sustainable integrated public transport system. The SSMP aims to contribute to reducing greenhouse gas (GHG) emissions, and favours the use of renewable energy for public transport.

- The municipal sustainable urban mobility plans (PMUS) as the main planning tool for setting mobility policies at the municipal level. The PMUS' overarching objectives are generally to ensure the quality of the environment, urban competitiveness, safety and universal access to transport. At the same 
time, the mobility plans serve as an instrument to coordinate the different departments within the local administration and guide infrastructure development.

- An extensive, modern and complex intermodal public transport system that consists of various modes of transport (metro, trams, suburban trains, buses), as well as an extensive network of shared e-bicycles. The transport network provides connections to other regions in the country, and inter and intra urban connectivity.

- The adoption of new and alternative modes of transport (e.g., e-biking, skateboards and rollerblades) by updating regulation to promote and facilitate their use while ensuring the safety of users and pedestrians. This has been the most recent action to improve the performance of the transport system to ease the movement of people.

However, enhancing urban accessibility requires acting on different fronts as transport policy alone is not able to facilitate greater levels of accessibility. For that, policy-makers in the Madrid Region may need to work together in at least three areas: transport policy, land-use planning, and regional development policy.

On transport policy, the CAM needs to reassess its progress on service quality and infrastructure. Supporting the shift to urban accessibility would require making the regional strategic transport plan legally binding. The current plan is merely a recommendation and not enforceable, thus limiting its impact. Transport investment in the CAM also requires a diversification of its funding and financing sources. The service requires large subsidies, and the regional government and Madrid city council are by far the main contributors to the financing of transport projects -- which may not be sustainable in the long term. In addition, the CAM must prepare for a wider adoption of digital technologies for better traffic management. One first action in this area would be a review and adaptation of the regulatory framework to enable innovation on smart mobility without hindering other desired societal outcomes such as equity, safety and efficiency. Another important area for the CAM is to anticipate risks and negative outcomes of micromobility by planning carefully for the appropriate adoption of these alternative modes of transport. Improving the state of the streets to enable walking and cycling should also be part of any transport strategy and urban renovation programme.

Regarding land-use planning, the CAM could conduct three complementary actions. First, the regional government could support municipalities, especially smaller ones, to prepare land-use plans by providing technical support, capacity building, and issuing policy guidelines. Second, regional and local authorities must ensure flexibility in the land-use planning system, in order to adapt to the changing context and priorities. This can be accomplished by establishing specific zones in a community designated for temporary uses and experimentation. Finally, with the participation of the central government, there could be a review of the fiscal framework to make it more compatible with and supportive of compact urban development.

Similarly, on regional development, the CAM could develop a comprehensive plan that provides a coherent and coordinated approach to sectoral policies towards a common vision. The current lack of regional planning is hindering urban development. Municipal governments may consider creating a metropolitan body for coordinating regional development and spatial planning, or giving this responsibility to the CRTM. This could reinforce the links between transport and spatial planning in the region. Moreover, to complement housing policies and promote a compact urban development, transport costs should be considered as being part of strategies to ensure housing affordability.

What lessons can be learned from the experience of the Madrid Region?

- A metropolitan or regional body in charge of public transport is key to unlocking the potential of the public transport sector in a highly fragmented region or metropolitan area.

- Creating a regional/metropolitan body for public transport requires technical capacity, political support, and a careful analysis of administrative and financial viability. 
- The introduction of an integrated fare structure facilitates coordination and standardisation in service provision.

- The adoption of an integrated transport system increases the efficiency of the different modes by complementing one another.

- The interoperability and mix of transport types is a way to achieve flexibility in commuting.

- Involving a wide range of stakeholders in the transport planning process is a way of building consensus and respond to real needs.

- Keeping pace with the new and alternative modes of transport is crucial for greater service efficiency. 


\section{Introduction}

For the City of Madrid and the larger Madrid Region, investing in public transport infrastructure is a tool to reduce pollution levels and minimise the negative impact on the environment, facilitate access to jobs, goods and services, and contribute to economic growth. However, the COVID-19 pandemic is threatening these efforts because of the lockdown measures adopted to control the spread of the disease. Residents' mobility habits are changing for fear of contagion. According to local authorities, between $10 \%$ and $13 \%$ of residents will switch from public transport to private vehicles as a result of the health crisis. ${ }^{1}$ The economic crisis of the post-COVID-19 period is expected to reduce travel needs due to unemployment. Local authorities expect a $20 \%$ reduction in the number of trips in the metropolitan area (from 10 million to 8 million trips per day). ${ }^{2}$

Moreover, a reduction in ridership also decreases revenue for public transport companies. During the three-month confinement (from 15 March to 21 June 2020) the use of public transport (mainly metro and bus services) decreased between $90 \%$ and $95 \% .{ }^{3}$ Since half of the operating costs are covered by ticket sales, the reduction in the number of passengers has created financial pressures for transport providers. For example, for the City of Madrid bus operator (Empresa Municipal de Transportes, EMT), the pandemic has led to a financial gap of EUR 150 million approximately. ${ }^{4}$

Another consequence of COVID-19 for mobility is the increase in the use of individual mobility devices (e.g., walking, bicycles, scooters, etc.). In Spain, biking increased $260 \%$ in May $2020 .{ }^{5}$ In the City of Madrid individual mobility devices are considered adequate to cover short distances and a way to avoid contagion. The transport authority in the Madrid Region has authorised private providers to expand their fleets of electric bikes to up to 4800 units more during the summer 2020 period. If the demand is met, the offer of electric bikes could reach 9600 units. BiciMAD, Madrid's bike sharing system, already has 2496 units operating and is being expanded as well. Thus, authorities expect that the total number of bicycles available to the capital residents will be three times higher than in $2019 .{ }^{6}$ This means that the use of individual means of transport are environmentally friendly, do not require much space, and their use has health benefits. However, for public transport operators, this means a reduction in the number of possible passengers and revenue.

What are the implications of the current health crisis for urban development and mobility in the City of Madrid and its metropolitan area? It is perhaps too early to come to draw definitive conclusions. However, a likely scenario is that the City of Madrid and the Madrid Region will have to meet three parallel challenges: contribute to economic recovery, prepare the region for future pandemics, and meet environmental and climate change mitigation goals. Public transport policies on their own will not be able to have a strong impact on those issues. They will need to be complemented by broader urban policies and, in the current context, authorities will need to design targeted investments that focus on responding to demand and 'pinch points', which could constrain growth. Inadequate transport investments could hold back economic recovery and growth. Infrastructure investments will be essential for re-building trust in public and active modes of transport. Quality transport infrastructure, as well as new and improved cycling networks, have the potential to ensure that sustainable modes of transport are more attractive and safer in the wake of the crisis. Improving residents' accessibility to jobs and services closer to where they live will likely be a critical part of the economic recovery and environmental protection efforts. Urban policies should not see private 
vehicles as the enemy, but should instead focus on incentivising people to use alternative mobility modes and access to opportunities.

The current health crisis gives the Madrid Region a window of opportunity to shift from focusing on mobility to enhancing accessibility. Promoting urban accessibility, which refers to how easily residents can reach local services and neighbourhood jobs either on foot, bicycle or using public transport (OECD, 2012[1]), is at the core of building compact, connected, clean and inclusive cities. According to OECD research, the COVID-19 pandemic has allowed cities to rediscover the benefits of proximity, which makes it easier for governments to implement effective policies to contain the virus (OECD, 2020[2]). This will require revisiting public space, urban design and planning practices. An adequate response to COVID-19 involves promoting building compact, connected, clean and inclusive cities to build resilience. Urban accessibility policies have the potential to contribute to each of these features of a resilient city. Focusing merely on mobility is likely to exacerbate the inequalities, low productivity, environmental problems, and low quality of life that prevail in many cities around the world.

This working paper will explore the experience of the Madrid Region and the City of Madrid in improving mobility and fostering accessibility as a way to pursue economic growth, well-being, and sustainability. The aim is to draw policy lessons that could inspire similar policies in other EU cities and beyond. The working paper will begin with a presentation of the institutional framework for transport policies in the Madrid Region. It will then discuss the regional development and transport planning instruments for the region. The working paper will then move on to describing the metropolitan public transport network and will assess its main strengths and weaknesses. The paper will conclude with a series of policies lessons on mobility and accessibility, and some practical and policy recommendations that could contribute to higher levels of accessibility. 


\section{Institutional framework for regional transport policies}

\section{Socioeconomic overview of the Madrid Region}

The Madrid Autonomous Community (Comunidad Autónoma de Madrid, CAM), or the Madrid Region7, is one of the 17 autonomous regions of Spain. It covers an area of $8022 \mathrm{~km}^{2}$, which accounts for approximately $1.6 \%$ of the Spanish territory. The region is landlocked in the centre of the country. The CAM is comprised of 179 municipalities including the municipality/city of Madrid, which is the capital of the country and one of the most important economic and financial hubs. ${ }^{8}$ The territory is divided into three functional zones called "coronas" (Table 1). The population is mainly established around the City of Madrid and it is therefore predominantly urban. The CAM has a population of 6.5 million inhabitants $(14 \%$ of the total national population) of which 3.2 million live in the city of Madrid. ${ }^{9}$ There are 100 municipalities with less than 5000 inhabitants each that represent $2.2 \%$ of the region's population. The 10 largest municipalities with more than 100000 inhabitants concentrate $73 \%$ of the total population (CRTM, 2013[3]). Some $65 \%$ of jobs are located in the municipality of Madrid alone (Table 1 ).

\section{Table 1. Number of jobs per zone in the CAM}

\begin{tabular}{l|l|r|r}
\hline \multicolumn{1}{c|}{ Regional zones } & \multicolumn{1}{c|}{ Features } & Number of jobs & \multicolumn{1}{c}{ Percentage } \\
\hline Zone A Madrid (Corona A Madrid) & Municipality of Madrid & 1812851 & $65 \%$ \\
\hline $\begin{array}{l}\text { Zone B Metropolitan (Corona B } \\
\text { Metropolitana) }\end{array}$ & $\begin{array}{l}\text { Municipalities around the City of } \\
\text { Madrid within a 20-km radius. }\end{array}$ & 906425 & $32.5 \%$ \\
\hline Zone C Regional (Corona C Regional) & $\begin{array}{l}\text { Small and medium-size municipalities } \\
\text { in the rest of the region }\end{array}$ & 69725 & $2.5 \%$ \\
\hline Total & & 2789002 & $100 \%$ \\
\hline
\end{tabular}

Source: (CRTM, 2013[3])

The Madrid Region generated one-fourth of GDP growth in Spain between 2000 and 2016.10 Madrid is the second economy in Spain after Cataluña, and the economy had been growing steadily since 2013 until the COVID-19 pandemic in 2020. In 2017, GDP reached EUR 210813 million, which translates into an average income per capita of EUR 33 809. This is the highest in the country and well beyond the national average of EUR 23970 (Instituto Nacional de Estadística)..$^{11}$ Unemployment decreased from $19.98 \%$ in 2013 to $13.52 \%$ in $2017^{12}$, but due to the COVID-19 pandemic unemployment has been increasing $(11.3 \%$ only in April $2020^{13}$ ). Over the last few decades, the economic possibilities of the region have attracted people from different regions of Spain and other countries, leading to an increasingly diverse society. In 2016, immigration from other countries represented $12 \%$ of the population. Migrants are mainly from other EU countries, Latin America and Africa.

Financial and insurance activities, commerce, transport and tourism are some of the main economic activities of the region. The main component of the regional gross value added is the tertiary sector that 
accounted for $82.6 \%$ of the total in 2016 , followed by the secondary sector that contributes to the remaining $10.1 \%$, of which construction represents $7.1 \%$. The city of Madrid receives over $60 \%$ of the direct foreign investment (EUR 13700 million in 2019) ${ }^{14}$, which enters the country particularly via real estate, storage and transportation. The region's telecommunications and transport network explains the success of the logistics companies in the CAM.

The CAM offers multiple business opportunities and a stable landscape for companies. Due to its central location and an extensive and modern telecommunications network, the CAM has access to a potential market of 1.3 billion people. The region has a high-capacity metropolitan road network and is the core of a radial infrastructure of roads and railways that connects it with the rest of the country and Europe. The CAM is connected by highway with most parts of Spain, France and Portugal. It is also the central node of the high-speed rail network (AVE) that connects the region with 17 provincial capitals. These economically important infrastructure developments have facilitated business trips, increased access to human capital, and strengthened the competitiveness of Madrid-based businesses. Moreover, the international airport (Barajas - Adolfo Suárez) facilitates access to any part of the world, and is Europe's main hub for Latin America.

Despite its comparative advantages with the rest of the regions in the country, the CAM faces critical challenges. Some of the main problems are an economy dependent on the construction sector, pockets of high unemployment, financial constraints on providing public services, rapid urban development with poor quality design and planning, urban sprawl, high immigration levels coupled with limited employment opportunities for immigrants, and threats to the quality of life (pollution, traffic, noise, and congestion).

Increasing urban segregation in the CAM is a source of concern as it can lead to instability. As Figure 1 shows, socio-economic segregation by income, job and employment status increased between 2001 and 2011. The two most important causes are income inequality and the concentration of cheap housing in specific neighbourhoods. Tackling urban segregation requires a multi-disciplinary approach as its origins could be rooted in several factors: social, geographic, cultural, etc. One possible action to address urban segregation is to ensure a mix of neighbourhood interventions and poverty reduction policies. Integrated policies should be part of the policy response where, for example, housing, land use, and transport policies are closely coordinated.

\section{Figure 1. Urban segregation in selected European urban areas}

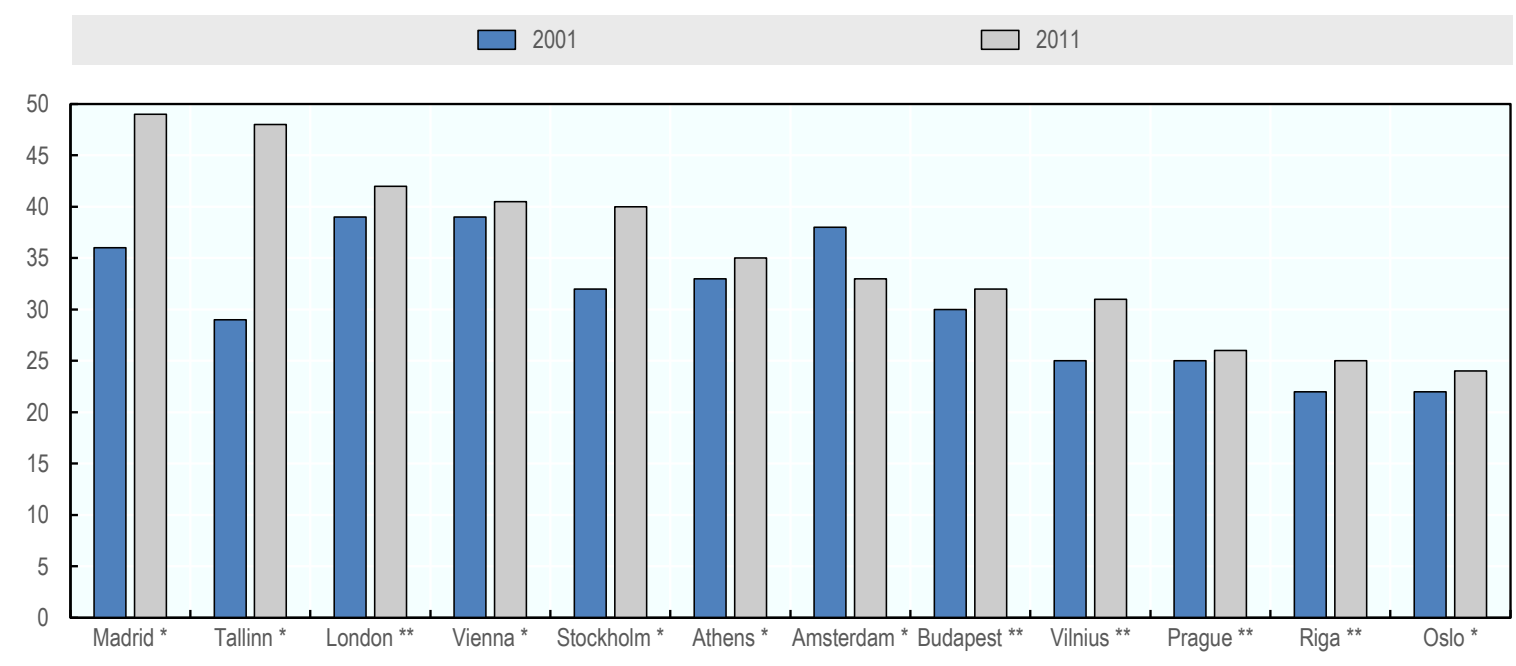

Note: *Metropolitan region ${ }^{* *}$ City proper

Source: (European Commission and UN-Habitat, 2016[4]) 


\section{A public transport authority for the entire region}

The Consorcio Regional de Transportes de Madrid (CRTM) is the public transport authority of the CAM. It was created by law 5/1985 of $16^{\text {th }}$ May of the Regional Government of Madrid as an autonomous and technical agency to coordinate public transport policies across municipalities and different providers. It is responsible for the integrated management of collective public transport in the CAM, but not for individual transport modes such as taxis, school transport or shared-bicycles. Each city council has jurisdiction over these transport modes.

As a transport authority, it acts in the strategic and tactical fields, leaving the operational tasks to operators. The CRTM is in charge of: I) planning public transport infrastructure; ii) establishing an integrated fare system for the whole public transport network; iii) developing a management policy and a stable and clear finance framework for the public transport system; iv) planning of services and defining the coordinated operational programmes for all transport modes; $v$ ) developing a policy of economic control; vi) auditing the integration of public transport with new urban planning; and vii) creating an overall image of the public transport system where CRTM holds the external relations with users (CRTM, 2016[5]).

The creation of the regional transport agency triggered the merger of public transport competencies across levels of government into one single agency. As Figure 2 shows, before the creation of the CRTM, every municipality was in charge of providing its own transport services, mainly through public buses. The City of Madrid and the regional government used to manage the metro service, while regional trains (Cercanías) were managed directly by the central government. The creation of the CRTM led municipalities to voluntarily transfer their transport management to the CRTM through a covenant and a commitment to cofinancing the transport service. One key incentive for a municipality to join the CRTM is that the regional government, through the CRTM, subsidises $50 \%$ of the cost of urban transport. There is also an integration of rates through a regional transport pass, which helps commuters save money when a more efficient route costs more. Moreover, the CRTM helps bridge transport planning capacity gaps in medium- and smallsized municipalities.

\section{Figure 2. Evolution of the institutional framework for public transport in the CAM}
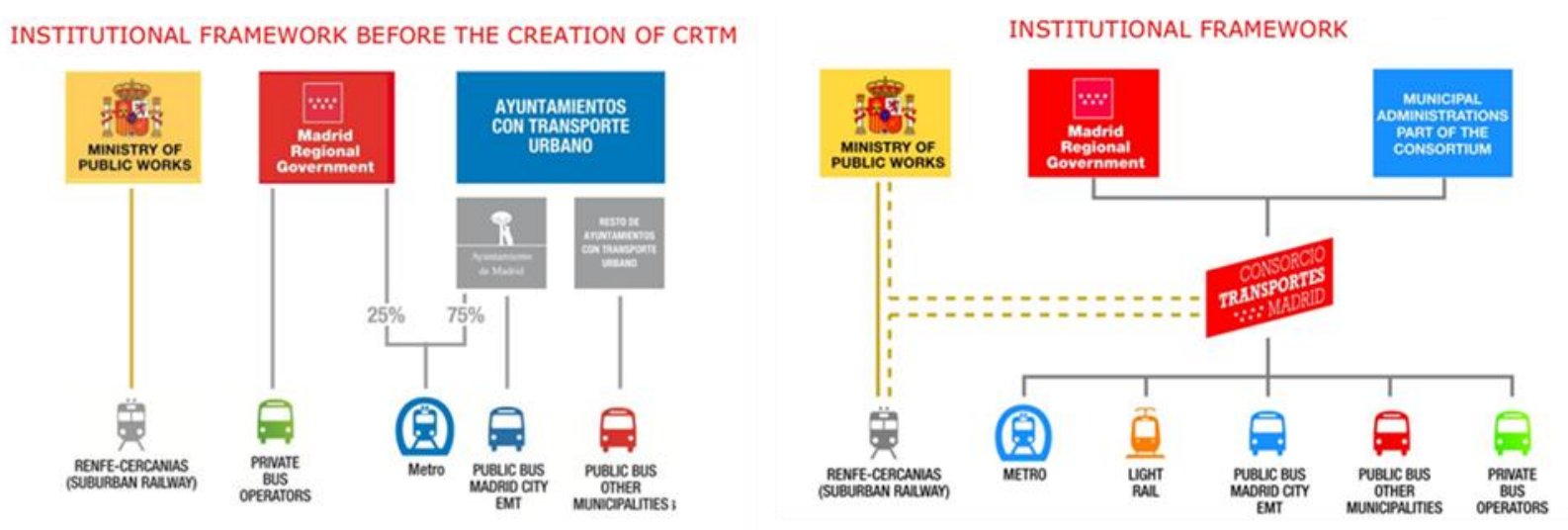

Source: (García Pastor, 2015[6])

The CRTM is a group of public administrations that act as a collegiate body, which implies that companies providing transport services are not directly integrated into the CRTM, but depend on it given that the municipalities, that are in fact responsible for the service, are part of the CRTM. According to Figure 2 Renfe Cercanías (suburban trains), a public company attached to the Ministry of Public Works (now Ministry of Transport, Mobility and Urban Agenda ${ }^{15}$ ), lies outside the consortium's sphere of competence, even though the central state administration, which contributes to the financing of the system, has 
representation on the CRTM board (CRTM, 2016 $[5])$. The operational framework of the regional public transport system in the CAM includes a wide network encompassing the metro, suburban trains, and buses (Table 1).

\section{Table 2. Operational framework of the CAM's public transport network}

\begin{tabular}{|c|c|c|}
\hline Type of transport & Operator & Description \\
\hline \multirow{3}{*}{$\begin{array}{l}\text { Passenger road } \\
\text { transport }\end{array}$} & Madrid Urban Bus (EMT) & $\begin{array}{l}\text { Public company held by the Municipality of Madrid. It provides urban } \\
\text { passenger transport in the City of Madrid. }\end{array}$ \\
\hline & $\begin{array}{l}\text { Urban bus operators in other } \\
\text { municipalities }\end{array}$ & $\begin{array}{l}\text { There are six urban transport concessions operating in six } \\
\text { municipalities, and one public company in the municipality of } \\
\text { Fuenlabrada. In addition, } 28 \text { municipalities provide urban services } \\
\text { through urban transport concessions. }\end{array}$ \\
\hline & Suburban bus operators & $\begin{array}{l}\text { There are } 27 \text { operators exploiting } 30 \text { suburban transport concessions } \\
\text { that provide services for all the municipalities in the region. }\end{array}$ \\
\hline \multirow{4}{*}{$\begin{array}{l}\text { Railway passenger } \\
\text { transport }\end{array}$} & Metro de Madrid & $\begin{array}{l}\text { A public company held by the Madrid regional government that } \\
\text { operates in nine municipalities. }\end{array}$ \\
\hline & Renfe Viajeros & $\begin{array}{l}\text { A public company held by the central state administration that exploits } \\
\text { the suburban railway network Cercanías de Madrid. }\end{array}$ \\
\hline & Private metro operators & $\begin{array}{l}\text { Two public works concessions for the extensions of both line } 8 \\
\text { (Barajas - Aeropuerto T4) and line } 9 \text { (Puerta Arganda - Arganda del } \\
\text { Rey), operated respectively by Metro Barajas S.C. and TFM. }\end{array}$ \\
\hline & Private light rail and tramway operators & $\begin{array}{l}\text { Three public works concessions for light rail lines: ML1 (Metros } \\
\text { Ligeros de Madrid), ML2 ML3 (Metro Ligero Oeste) and ML4 tramway } \\
\text { (Tranvía de Parla). }\end{array}$ \\
\hline Interchange stations & \multicolumn{2}{|c|}{$\begin{array}{l}\text { There are five public work concessions, including operating and maintenance of the interchange station of } \\
\text { Madrid. }\end{array}$} \\
\hline
\end{tabular}

Source: (CRTM, 2016[5]).

The CRTM governing body is the board composed of 20 members under the principle of 'one seat, one vote'. The members of the board are the regional government $(7$ members), the municipality of Madrid ( 3 members), other municipalities of the region ( 3 members), the national government (2 members), private operators' association (2 members), trade unions (2 members) and the association of consumers (1 member). The Regional Minister of Transport is the president of the CRTM and nominates the General Manager. The Madrid City Councillor for Transport is the vice-president; and six members sit on the executive board.

The creation of the CRTM has contributed to a stronger coordination between municipalities and regional authorities on transport investment planning, but coordination still relies on informal mechanisms. The CRTM is responsible for the coordination of transport services, while the municipalities are responsible for building the transport infrastructure. Collaboration between the CRTM and the municipalities is strong on a technical level, but lacks formality. It depends more on the goodwill of officials than on institutional arrangements. For example, in the municipality of Alcalá de Henares, mobility authorities have been working closely with the CRTM to redesign bus routes and the frequency of service to increase efficiency. The bus operators are coordinated by the CRTM, but the municipality provides the road works necessary for the service. Similarly, the municipality is working with the CRTM to put into service a line of express buses to Madrid to reduce commuting time, as well as a direct bus line to the airport.

The CRTM has been the central actor in the development of the transport network, and of expanded mobility options in the CAM. However, the CRTM's competencies are limited to collective public transport. Projects to promote walking and cycling, as well as the planning and management of parking areas, are outside its purview. The CRTM must also work towards the integration of other modes of transport (taxis, bicycles, car sharing, etc.) to expand transport accessibility. Although the CRTM is autonomous, it is not 
immune to the political fluctuations that can have a negative effect on coordination. Its chief executive can be selected via an open contest rather than a political appointment.

\section{Financing of the public transport system}

Funding for public transport in the CAM comes from a combination of contributions and subsidies that are coordinated through an investment programme managed by the CRTM. The financial needs of the transport system rely on a compensation per service paid for by the CRTM and supplied to the different operators, funded by public contributions from all levels of government (central, regional and municipal governments), and farebox revenue. The three levels of government have agreed on an investment programme in which each has committed to provide a percentage of the resources for a determined period. The CRTM manages the investments, then each operator or service provider receives the investments and the exploitation gains according to the use of the transport system.

The CRTM has a special legal regime that requires two different budgets (Figure 3 ). On the one hand, an estimated budget compiling all commercial activity that integrates, on the income side, those derived from ticket sales, and on the expenditure side, the distribution of this income among the transport operators, and the distribution and sale of ticket costs. On the other, an administrative budget integrates tax collection and other public law revenues. On the expenditure side, this budget includes all necessary credits to finance personnel expenditure of the entity, as well as current expenses on goods and services. In 2016, CRTM's revenue amounted to EUR 2110 million whereas the expenditure was EUR 2064 million, which represents a surplus of EUR 45.6 million (CRTM, 2016[5]).

\section{Figure 3. CRTM special budget regime - two different budgets}

$$
\begin{aligned}
& \text { 1. Commercial activity } \\
& \text { - Income side - tickets sales } \\
& \text { - Expenditure side - distribution of income among } \\
& \text { transport operators and costs of distribution and } \\
& \text { commercialization of tickets } \\
& \text { 2. Administrative } \\
& \text { - Income side - revenues stipulated in public law: } \\
& \text { taxes } \\
& \text { - Expenditure side - staff costs and expenditure on } \\
& \text { goods and services }
\end{aligned}
$$

\section{Administrative}

Source: (CRTM, 2016[5])

The central government uses a general financing system to fund the transport system in municipalities of over 50000 inhabitants. The central government allocates the funding based on three parameters: i) subsidy for the length of the network (5\%), ii) subsidy for demand (5\%), and iii) subsidy for deficit from ticket sales $(90 \%)$. The problem with this scheme is that it favours those operators that have a larger deficit in their operations. The number of cities entitled to receive funds from this subsidy has been growing from 64 in 1990 to 91 in 2014. Therefore, the subsidy now covers only $10 \%$ of the financial gaps, whereas it was one-third back in 1990.

Annual agreements govern the payments for the largest operators: Metro de Madrid, Empresa Municipal de Transportes de Madrid (EMT) and Renfe. For the case of Metro de Madrid the agreement is based on the approval of a balanced ticket price per passenger. For Metro de Madrid and EMT the agreements 
include concrete quality service objectives. Lastly, the agreement with Renfe regulates the use of the multimodal transport tickets (the travel pass) and the revenue it generates. Economic relations with the private operators of road passenger transport are established in public service contracts.

Although this model has produced good results and helped build a high quality transport system, there are challenges in meeting the costs of global investments, as well as financing problems in recent years (Ruiz Montañez, 2014[7]). The financial sustainability of the transport system seems to be a challenge as over $57 \%$ of its income comes from subsidies and almost $43 \%$ from ticket sales (Table 2). The regional government is by far the main contributor to the system with $44 \%$ of the subsidies followed by the City of Madrid and the central state administration. The city councils of the CAM with urban transport services also contribute to the financing, but to a much lesser extent.

Table 3. Financing of the transport system in the CAM

\begin{tabular}{|c|c|c|}
\hline Public subsidies & $\begin{array}{c}2016 \\
\text { (millions EUR) }\end{array}$ & Percentage \\
\hline Central administration & 126.7 & 5.70 \\
\hline Madrid region (CAM) & 980.1 & 44.11 \\
\hline Madrid city & 149.1 & 6.71 \\
\hline Other cities & 14.1 & 0.63 \\
\hline Total & 1270 & 57.16 \\
\hline Fee revenues & 952 & 42.84 \\
\hline Total & 2222 & 100 \\
\hline
\end{tabular}

Source: (Velasco, 2016[8]) 


\section{Regional development and transport planning instruments}

\section{Lack of a formal regional development strategy}

In the CAM, although regional planning for development is legally possible, there is no a development plan or other instrument that guides economic, land use, transport, housing and environment policy at regional scale. Thus, urban and development plans are circumscribed to the administrative boundaries of municipalities. Indeed, each municipality conducts planning in many different domains such as urban and transport development, but there is no document that presents a vision of how all municipalities see the CAM in the medium and long term. A regional development plan could cut across the administrative and geographical boundaries to give a more holistic view of the region, and coordinate all development efforts. Four regional plans were elaborated in the past but never approved. This is a critical issue because economic development processes happen within the wider geographical area than that of the municipality. This implies that substantial inter-governmental cooperation for development at local level is required and this is normally guided by a regional development plan.

The CAM has the competence of approving the land use plans of the 179 municipalities of the region and all the different regional sectorial plans in areas such as land use, infrastructure, environment, water, energy system, mobility, education and social services, culture and tourism. The CAM revises the municipal urban plans to ensure they have followed the legal process, but there is little discussion on their regional implications. There seems to be a need for a regional plan that guides regional growth. For instance, because municipalities get most of their financing via housing, most mayors look for ways to increase the number of people living in the municipality without considering all the implications this may have in terms of mobility, environment and service provision.

A key limitation in the region is the lack of a strategic vision for development. Municipal governments do not generally commit to projects of more than four years, which makes it difficult to adopt a long-term development vision. The region is managed in a concerted way but with little planning. There are no orientations or general guidelines for development. Economic development outcomes materialise in a period that is closer to the business cycle (12-15 years) than to the electoral cycle (4 years). That is why regional development should be seen as a partnership activity among public, private and voluntary sectors with substantial vertical and horizontal collaboration on the public sector side.

\section{The Strategic Sustainable Mobility Plan for the Madrid Region}

Transport planning in the Madrid Region is framed within a series of international, national, regional and local mobility plans (Figure 4). The European Commission has formulated some recommendations on urban mobility through a series of reports, policy recommendations and exchange of experiences. Those recommendations have influenced the Spanish Strategy on Sustainable Mobility that explains how to plan transport services and infrastructures at regional level, giving priority to accessibility, active mobility and public transport. Based on this framework, the CRTM developed the Strategic Sustainable Mobility Plan of 
the CAM (SSMP) 2013-2025 to coordinate the transport efforts of the different local governments in the region. The SSMP presents the vision of what public transport should look like in 2025: an efficient, safe and sustainable integrated public transport system. The SSMP aims to contribute to the reduction of GHG emissions and favours the use of renewable energy for public transport.

\section{Figure 4. Transport planning framework for the Madrid Region}

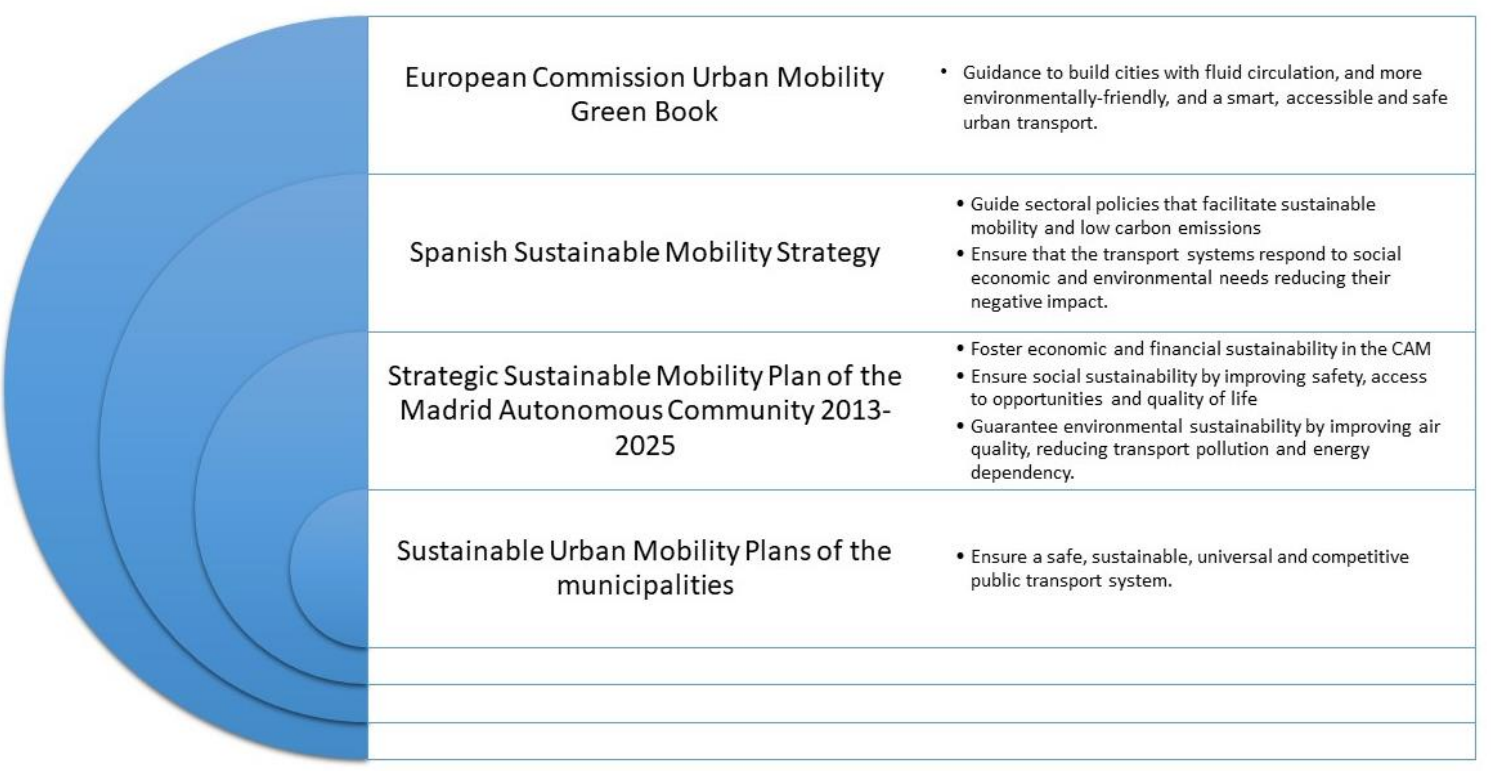

Source: (CRTM, 2013[3]) (Ministerio de Fomento, 2018[9])

The SSMP aims to achieve its objectives by promoting a model based on four pillars:

- Administrative integration: this began with the creation of the Consorcio Regional de Transportes de Madrid (CRTM) as the sole public transport authority for the CAM and the local governments that are a part of it.

- Fare integration: this was achieved with the introduction of the 'travel pass' currently used for more than $70 \%$ of transport journeys. The integration of the fare system at regional level is the key characteristic of public transport in the CAM (Box 1)

- Modal integration: which refers to the complementarity of all the different transport modes to achieve intermodality.

- Technological integration: which refers to the integration of data, formats, protocols and processes between operators, customers, and authorities (CRTM, 2013[3]). 


\section{Box 1. Integration of the fare system in the CAM}

The fare system is designed to make travelling by public transport affordable and easy to use. There is a wide range of ticket options, among them, the multimodal and integrated travel card provides an unlimited number of trips during a month or a year. This travel pass can be used in buses, metro and railways in the region within the validated zone. There are monthly passes for different population groups: the standard pass for users between 26 and 64 years old (between EUR 54.60 - 99.30); the youth pass for people up to 25 years old (EUR 20); the senior pass for people aged over 65 years old (EUR 12.30); the child pass for children between 4 and 6 years of age; and the unemployed pass for participants of the employed activation plan (EUR 10).

Despite the advantages of the integrated ticketing system, some (Cristóbal Álvarez, n.d. ${ }_{[10]}$ ) consider that there is a problem with the rate system, as it is complex and determines the ticket price based on the circumstances of the user (age, disability and number of family members). This has led to a system where some people pay a higher price for the same service. Two consequences have been that operation costs are not recovered and the public that pays the higher prices prefer to look for other alternatives for travelling (Cristóbal Álvarez, n.d.[10]). The complexity of the tariff system may be because transport is used as an instrument of social policy. Authorities in the CAM may need to discuss alternatives to get the price right, ensuring a balance between social objectives and the financial needs of the transport system. A well-financed transport system is vital to the continued improvement, maintenance and expansion of the transport network. The CRTM needs to get its fares right to cover operational costs, the environmental and congestions cost of transport, to encourage technological innovation, to promote greater equality of opportunity and behavioural change.

Source: (CRTM, 2013[3]); (Cristóbal Álvarez, n.d. $[10])$

Concretely, the SSPM includes 265 actions organised around 12 strategic measures (Table 3). Around $45 \%$ of the actions in the Plan are exclusively related to public transport. The latter highlights two points, first the prominent role of public transport in achieving the sustainable mobility vision, and secondly the acknowledgement of the experience of the transport authority for implementing sustainable mobility measures. Moreover, the SSMP shows the impact of adopting a holistic approach to promote mobility as it requires the alignment of different policy sectors.

\section{Table 4. The Strategic Sustainable Mobility Plan of the CAM 2013-2025}

Actions related to public transport

\begin{tabular}{|c|c|c|c|}
\hline Measures & $\begin{array}{c}\text { Total number } \\
\text { of actions }\end{array}$ & $\begin{array}{c}\text { Number of actions related to } \\
\text { public transport }\end{array}$ & $\begin{array}{c}\text { Percentage of actions related } \\
\text { to public transport }\end{array}$ \\
\hline Traffic control and road regulation & 48 & 2 & 4.1 \\
\hline Private vehicle management & 4 & 0 & 0.0 \\
\hline Enhancement of public transport & 45 & 45 & 100 \\
\hline Improvement of urban quality & 14 & 8 & 57 \\
\hline Mobility management & 8 & 3 & 37.5 \\
\hline Universal accessibility & 15 & 15 & 100 \\
\hline Freight transport & 3 & 0 & 0.0 \\
\hline Integration of mobility in urban planning & 5 & 1 & 20 \\
\hline Energy saving and environment & 52 & 14 & 27 \\
\hline Commuting transport plans & 21 & 10 & 48 \\
\hline Road safety & 37 & 12 & 32 \\
\hline Working group evaluation & 13 & 10 & 76.9 \\
\hline Total & 265 & 120 & 45.3 \\
\hline
\end{tabular}

Source: (Sobrino, 2016[11]). 
The SSMP has some limitations that are preventing it from becoming a decisive document to guide decisions in terms of transport policies. First, the SSMP is not a binding document, and therefore public investments in the plan are subject to political decisions. It is therefore a more technical document than a strategic policy document as it contains a number of investment project proposals that require regional government's approval to be realised. Second, the SSMP is not integrated in other key policies that have a direct impact on transport policies (e.g. land use planning). Despite its contributions to improving transport in the CAM, the SSMP lacks integration with regional and land use planning. There is no evidence that the transport mobility strategies, programmes or projects incorporate considerations on how the CAM will grow demographically and economically. This is relevant because "[t]he integration of planning and the development of public transport... and land use is increasingly recognised as a potentially effective mechanism for achieving long-term public transport goals of functionality and competitive capacity" (Hrelja, 2015 , p. $\left.1_{[12]}\right)$. The reasons for this may be that there is no regional development plan; there is not a regional body in charge of planning; municipalities have individual responsibility for planning but they do not always coordinate with the neighbouring municipalities; and regional planning requires a long-term vision, which is incompatible with the short termism associated with political mandates. Lastly, the SSMP was not elaborated in consultation with the municipalities and thus it represents the vision of the regional government. Moreover, the SSMP has not been communicated across municipalities and many are not aware of its content.

\section{Municipal Sustainable Urban Mobility Plans}

A number of municipalities in the Madrid Region have issued a Sustainable Urban Mobility Plan (Plan de Movilidad Urbana Sostenible, PMUS). The PMUS is a strategic plan designed to meet the mobility needs of people and businesses in cities and their surrounding areas. It is the main planning tool for setting mobility policies at municipal level. The PMUS overarching objectives are generally to ensure the quality of the environment, urban competitiveness, safety and universal access to transport. At the same time, the mobility plans serve as an instrument to coordinate the different departments within the local administration and guide infrastructure development.

The elaboration of the PMUS normally involves interviews with the key actors in the mobility domain, fieldwork (e.g. surveys, citizen fora), a pre-diagnostic of the main challenges, citizens' input (gathered through internet tools), and a final diagnostic. The PMUS define priorities, actions, future scenarios, as well as the necessary conditions for their implementation. The CRTM and the Institute for the Diversification and Energy Savings (Instituto para la Diversificación y el Ahorro de Energía, IDAE) have supported municipalities in the elaboration of their PMUS. According to the regional government, $85 \%$ of the inhabitants in the region live in a municipality that has an updated PMUS (5.4 million inhabitants) (CRTM, $\left.2013_{[3]}\right)$. Most of the larger municipalities have issued a mobility plan and those include the City of Madrid (3 230000 inhabitants), Getafe (170 100 inhabitants), Mostocles (205 000 inhabitants), Rivas-Vaciamadrid (72 900 inhabitants), Majadahonda (70 000 inhabitants), Valdemoro (68 000 inhabitants), Fuenlabrada (198 600 inhabitants), among others.

The PMUS generally give priority to managing travel demand through increasing the volume and capacity of the transport system. However, the PMUS do not normally reflect on how people could reach services and goods at lower costs, in less time and in a more sustainable manner. The PMUS does not propose ideas about how residents can shorten their distance to jobs, goods and services or even eliminate the need to travel at all. Some examples of PMUS in the CAM are:

- The city of Madrid has established a PMUS based on four pillars: sustainability, universal accessibility, competitiveness and safety. Different policy areas participated in its elaboration providing an interdisciplinary approach and ensuring the alignment of administrative 
departments (Box 3.2). Critically, the PMUS considers mobility a factor to achieving social cohesion together with housing, health and education.

- In the municipality of Alcobendas, one of the most industrial areas in the CAM, the PMUS aims to: i) reduce congestion, noise, pollution and accidents; ii) minimise the consumption of non-renewable energy; iii) shorten travel times; and iv) improve accessibility conditions, the quality of public transport, and the urban environment (Municipality of Alcobendas, $2010_{[13]}$ )

\section{Box 2. The city of Madrid's mobility plan}

The Sustainable Urban Mobility Plan of the City of Madrid is a management tool to structure mobility policies based on the general objectives for environmental quality improvement, competitiveness, safety, and universality. The objectives of the Plan are grouped in four pillars Safety, Universality, Sustainability and Competitiveness to achieve the city's strategic vision (Figure 5). On safety, the aim is to reduce the number of accidents and change behaviour patterns (i.e. reduce $30 \%$ the number of victims per 1000 inhabitants by 2020) to make users respect the modes of transport. On sustainability, the aim is to reduce the negative impact on the environment (i.e. reduce by $30 \%$ total GHG emissions in the municipality of Madrid by 2020 in relation to 2005 levels). Regarding universality, the aim is to facilitate access to the different services the city offers such as employment, health, education, shopping and leisure. For that, the Plan intends to continue to focus on sustainable mobility options such as walking and cycling rather than private cars. On competitiveness, the Plan intends to reduce travel time and, consequently, the costs incurred in commuting. One way of doing that is by improving the speed of public transport (i.e. an increase of $3 \%$ of buses' speed).

\section{Figure 5. The mobility system of the city of Madrid}

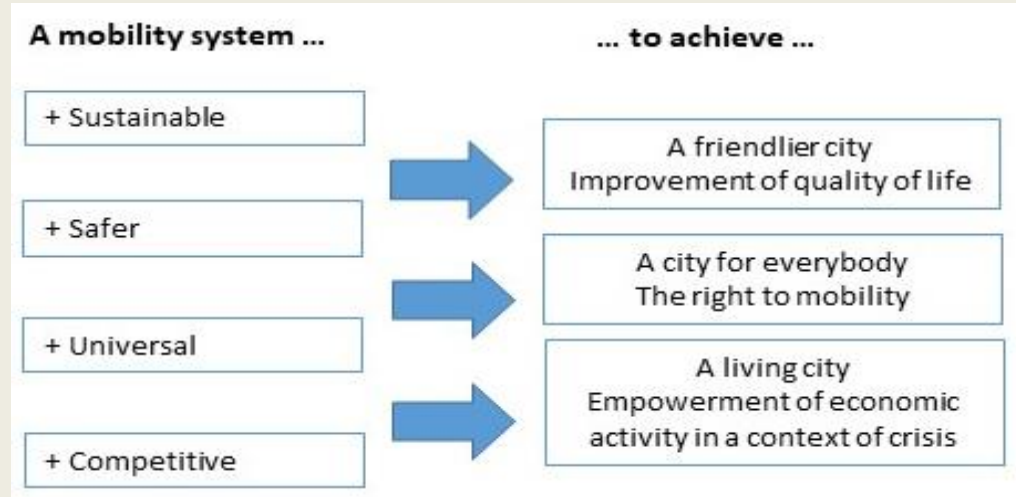

Source: (Municipality of Madrid, 2014[14]]

The PMUS is aligned with other relevant urban plans in the municipality, thus streamlining the implementation of the different sectoral plans (Table 5). The PMUS includes a follow-up mechanism for the continuous assessment and revision of the plan, allowing it to adapt to changing conditions. 


\section{Table 5. Municipal plans with an impact on mobility in the City of Madrid}

\begin{tabular}{|c|c|}
\hline Municipal plans & Mobility reference \\
\hline General Urban Plan of Madrid & $\begin{array}{l}\text { It sets the conditions for parking spaces and transport infrastructure as well } \\
\text { as pedestrian areas and the reorganisation of space for the circulation of } \\
\text { vehicles and people }\end{array}$ \\
\hline Local Strategy for Air Quality of the City of Madrid & $\begin{array}{l}\text { It establishes measures for traffic reduction in priority areas of the city, and } \\
\text { the promotion of public transport. }\end{array}$ \\
\hline Road Safety Plan & It supports one of the pillars of the mobility model: safety \\
\hline Cycling Mobility Director Plan & $\begin{array}{l}\text { It includes four programmes: infrastructure, regulation, promotion and } \\
\text { management of the network of cycling paths. }\end{array}$ \\
\hline Action Plan on Noise Pollution & $\begin{array}{l}\text { To reduce noise levels it proposes the use of quieter vehicles, the use of } \\
\text { public transport, and reduction of speed. }\end{array}$ \\
\hline $\begin{array}{l}\text { Plan for the Sustainable Use of Energy and } \\
\text { Prevention of Climate Change }\end{array}$ & $\begin{array}{l}\text { Its objective is to promote low carbon mobility through sustainable transit } \\
\text { modes such as walking, public transit, cycling and electric vehicles. }\end{array}$ \\
\hline
\end{tabular}

Source: Based on (Municipality of Madrid, 2014[14]]).

The Mobility Tables (Mesas de Movilidad) are the key instruments for the design of the PMUS. They gather policy-makers and technicians as well as civil society actors with key responsibilities in mobility issues for consultations on municipal urban mobility. Their value-added is that it allows the issue of mobility to be analysed from different angles and policy sectors (i.e. air quality, security, urban development, etc.). The Tables represent an opportunity for dialogue and knowledge sharing as well as to set a common long-term vision. For instance, in the municipalities of Madrid, Alcobendas and Alcalá de Henares the Mobility Tables have facilitated discussions on specific mobility challenges:

- In the City of Madrid, the Mobility Table enabled the adoption of a roadmap and a system of indicators (Informe del Estado de la Movilidad, IEM) that were the basis for the definition of a model and global mobility strategy that included the actions undertaken by the different administrative areas of the city administration.

- In the municipality of Alcobendas, the Mobility Tables hold meetings every 3 to 4 months that are chaired by the city council. The main problem they address is mobility to job centres and the possibility of having a special road lane for buses and bicycles to improve mobility within the municipality.

- In the municipality of Alcalá de Henares the Mobility Tables are a channel for citizens to get information and provide feedback on different mobility issues. In this forum, municipal authorities organised a working group including officials from traffic, heritage, urban development departments, etc. to redesign the municipal bus routes to improve accessibility to services. 


\section{The metropolitan public transport network}

\section{The CAM has a vast public transport network}

The Madrid Region has an extensive and complex intermodal public transport system that consists of various modes of transport (Figures 6 and 7). The transport network provides connections to other regions in the country, and inter and intra urban connectivity. Two major subsystems can be distinguished: i) the urban area of the City of Madrid with over 200 urban bus routes (EMT), 12 underground lines (Metro), one light rail line and 37 suburban train stations; and ii) the metropolitan area of the region with over a hundred urban bus routes, over 300 suburban lines, 5 metro lines, 3 light rail lines and 9 suburban railway lines (CRTM, 2013 ${ }_{[15]}$ ). Both systems are connected by a series of large interchanges (intercambiadores) that surround the central area of the City of Madrid, channelling radial mobility between the capital and its metropolitan zones/rings. The transport network provides service to all the municipalities in the CAM. Practically the entire territory of the municipality of Madrid is covered by some form of public transport. Sixty-six percent of the population of the municipality of Madrid has a metro station in a radius of 600 meters (10-minute walk approximately) (CRTM, 2016 $\left.6_{[5]}\right)$. In recent years the bus lines have increased 40\% across the city.

Figure 6. Classification of public transport in the Madrid Region

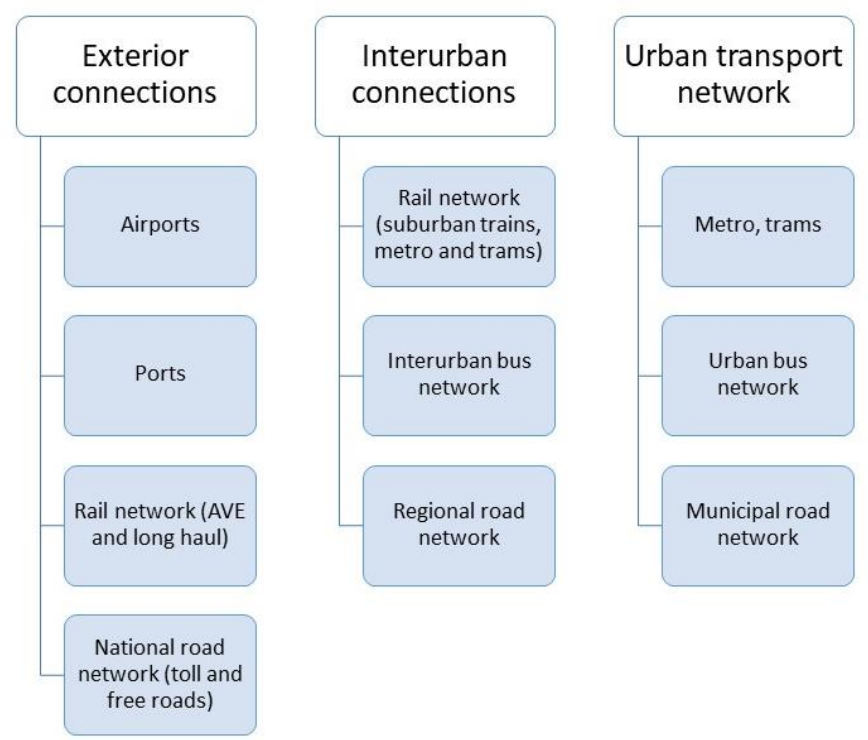

Source: Presentation to the OECD given by officials of the Comunidad de Madrid on 9 October 2018 
Figure 7. The integrated transport network of the Madrid Region

Metro, light rail and suburban rail of the CAM

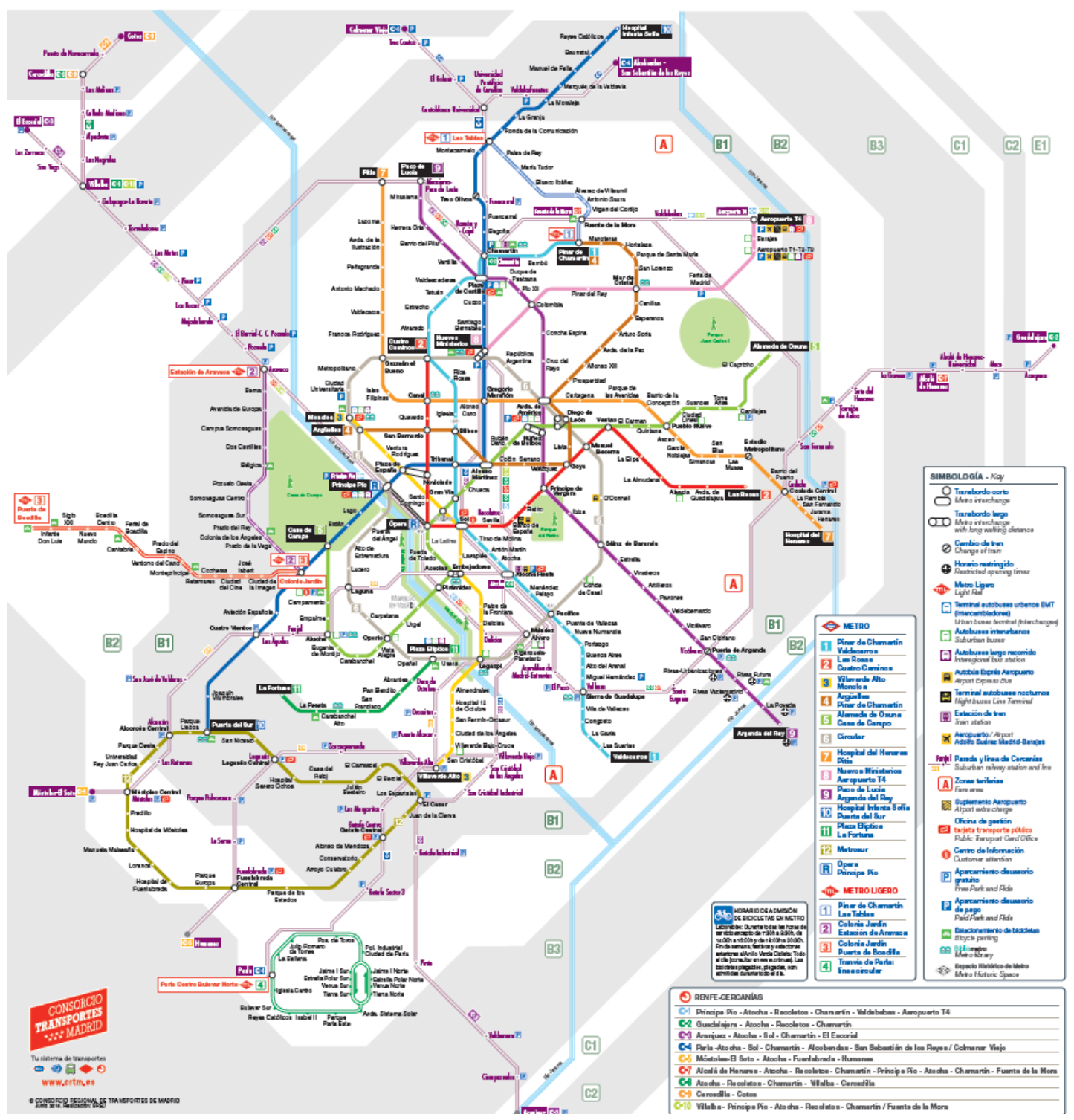

Source: Map provided by the CRTM: www.crtm.es/media/146545/serie_0c_esqredintegrada.pdf.

\section{The CAM has a modern rail transport network}

After completion of its most recent extension plan, the metro network is 287 kilometres long and has 238 stations distributed over 12 lines. In 2016, it provided service to over 585 million passengers. Since 1991 the regional government has implemented a number of extension plans of which the 2003-2007 plan marked a milestone in extending and modernising the Metro network. The rolling stock has increased by $50 \%$ over the last years and is made up of 2320 carriages and the average age is 16 years old (CRTM, 2016[5]). However, the network has a transversal design that penalises cross-sectional commuting. Moreover, areas that are located away from the centre have less coverage and many of the areas of economic activity have no access to the metro. 
The CAM has a modern suburban rail network. Cercanías-Madrid is a railway service operated by Renfe Viajeros (the national rail transport operator), which connects the City of Madrid with its metropolitan area and with the city of Guadalajara. The current network consists of nine lines with 94 stations covering 391 kilometres, including three stations outside the territorial jurisdiction of the CAM: Azuqueca, Cotos and Guadalajara (CRTM, 2016 $\left.6_{[5]}\right)$. In recent years, the network has seen major changes. The most important modernisation project was the opening of the new Atocha-Chamartin tunnel in 2008. The 8.3 kilometre long tunnel has allowed the number of trains in the most heavily-used section of the network to be doubled, thus resulting in a considerable reduction in journey time for users. It has also improved the flow of traffic in the city centre (CRTM, 2013 $\left.{ }_{[15]}\right)$. In 2011, the access to Barajas international airport terminal 4 became part of the Madrid suburban rail network facilitating the connection between the new airport terminal and the city centre.

Light rail transit (LRT) systems are becoming an integral part of the transport network in the CAM. The region operates four LRT lines concessioned to three different companies. The system meets transport needs in medium-density urban areas and towns and also acts as the main transport link between outlying areas and the high-capacity transport networks.

\section{A mix of public and private operators provide bus services in the region}

The urban bus network of the City of Madrid, operated by Empresa Municipal de Transportes de Madrid (EMT), is composed of 211 lines of which 25 are night lines. The entire population of the city of Madrid has access to a bus stop within a radius of 350 metres (5-minute walk) (CRTM, 2016[5]). The bus network has expanded as the city's population has grown. Its expansion has been based on planning conducted by the CRTM and in coordination with the municipalities. However, traffic jams affect the quality of the bus service, as there are no dedicated bus lanes. Although the bus network covers the entire city, there has not been any specific planning to bring more order and increase the efficiency of the lines and service. EMT has conducted some studies to reorganise the entire bus network, but the possibility of social protests hampers any bus network reorganisation. In the municipality of Alcalá de Henares the local council is currently reorganising the bus network with the CRTM technical assistance. The problem was that all lines converged in the city centre and that increased congestion and decreased the efficiency of the service. Since the city centre has the UNESCO human heritage status and citizens wanted to walk more freely in the streets, the local council started the reorganisation of the network. The expected effect is better accessibility as travellers do not necessarily have to traverse the downtown when going from one point to another, and traffic may improve.

The bus network of the road transport concessions of the CAM is formed by 440 lines of which 227 are suburban day lines, 112 urban lines and 31 suburban night lines. These lines are operated by 31 different companies under 36 administrative concessions and agreements with city councils. The urban service in the municipalities of zones $B$ and $C$ is provided by urban lines of the municipality or by the suburban bus network. In some municipalities, the urban service is provided by a combination of the two networks (CRTM, 2016[5]). Since 2012, a total of 38 municipalities plus the City of Madrid, had their own specific network of urban bus routes, all dependent on the CRTM (CRTM, 2013 ${ }_{[15]}$ ). In the municipality of Fuenlabrada, for instance, the city council provides the urban service through a local public company (CRTM, 2016[5]). The municipality of Alcalá de Henares has a bus network with 11 routes and 58 buses that moves 9.9 million passengers per year (CRTM, 2013[15]). Due to the importance of the suburban bus network for mobility between the metropolitan area and the City of Madrid, the CRTM has been working to strengthen this service through different initiatives to improve the quality and quantity of the service. Some initiatives include programmes for bus platforms on roads with the BUS-HOV (high occupation vehicles) and the BUS-ONLY section when approaching the city itself. 


\section{6}

\section{Intermodal points facilitate transfer to higher capacity modes of transport}

The intermodal points is one of the features of the region's public transport infrastructure. They permit the different transport networks to converge in hubs, by streamlining intermodal mobility and making it easier to transfer to high capacity modes of transportation. The intermodal points are classified according to their infrastructure in three groups: interchange terminals (intercambiadores), intermodal areas and exchange points. The interchange stations have a critical role in access and dispersion of the metropolitan trips, while the intermodal areas and the rest of exchange points supply trips in the urban area. The interchange terminals act as the access gateways of Madrid's public transport (suburban buses and suburban trains) optimising accessibility to the mainly urban transport modes. There are twelve principal metropolitan intermodal points in the City of Madrid of which five are interchange terminals managed by the CRTM. One in two trips in the entire region goes through one of these twelve nodes (CRTM, 2016[5]). 


\section{The state of mobility in the Madrid region}

\section{Private car travel remains the main mode of transport}

The location of economic activity and areas of residence and services largely dictates the flows of people in a region. In the CAM this is translated in commuting trips that are done totally or partially by motorised means. The total number of trips in the CAM during a weekday is 16 million of which $70 \%$ approximately are made by mechanised modes (private vehicle and public transport) (CRTM, 2013[3]). Figure 8 shows that the private vehicle is still the most popular way of getting around in the Madrid Region. In some areas outside the City of Madrid, the use of the car may reach more than $50 \%$ as transport coverage is lower. For example, in the municipality of Alcobendas, in the outskirts of the City of Madrid, $57 \%$ of the trips were done by private car in 2010, a slight reduction from the $61 \%$ registered in 2004, whereas the use of public transport registered an increase from $22 \%$ to $28 \%$ in the same period (Municipality of Alcobendas, $2010_{[13]}$ ). The increase of commercial centres in the periphery supported by the highway network but cut off from the urban fabric, has also contributed to greater activity levels in the suburbs and the use of cars. Up until the outbreak of COVID-19, the use of private cars was decreasing (albeit slowly). The number of drivers' licenses issued in the CAM has decreased in the last decade from more than 154000 in 2008 to just over 87000 in 2018. ${ }^{16}$ This data could reflect a growing preference for alternative modes of transport, i.e. a shift away from cars. In the City of Madrid, in 2012, there were 1.72 million cars registered and the figure has not varied much since 2005.

The use of motorcycles has increased. The number of motorcycles registered in the CAM passed from more than 258000 in 2008 to over 364000 in 2018. ${ }^{17}$ While motorcycles have the potential to increase access to different opportunities and require less space, an increase in the share of motorcycle trips has raised concerns related to the sustainability of this mode (pollution and noise) as well as issues related to road safety. Figure 8 also shows that a large percentage of citizens prefer walking (30\%). This has been favoured by the fact that three-quarters of the trips in the city of Madrid cover distances of less than five kilometres. ${ }^{18}$ 
Figure 8. Modal share of total trips in the CAM

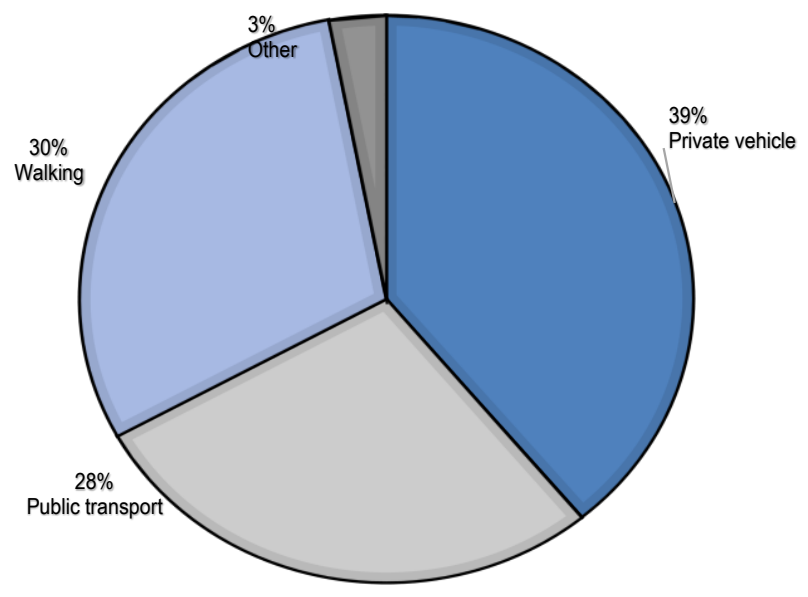

Source: (Velasco, 2016[8])

Demand for public transport in the CAM has remained relatively stable over the last ten years (Figure 9). This data could vary depending on the municipality. According to the EU, the city of Madrid is among the top 10 European capitals with the highest level of public transport use where $42 \%$ of the trips are done via public transport and $29 \%$ by private vehicle (European Commission and UN-Habitat, 2016[4]). Some of the reasons for these results are the increase in the public transport offer and the lack of parking spaces. These data also suggest that more investments may be needed to incentivise the use of bicycles. In Madrid, like in the large majority of EU capitals, cycling does not reach more than a $10 \%$ modal share, Madrid's share is below even 5\%. Other Spanish cities such as Barcelona and Malaga have slightly higher shares of bicycle use (European Commission and UN-Habitat, 2016 $\left.6_{[4]}\right)$. Public transport demand has risen $52 \%$ since 1986 while the population has increased 36\% (Velasco, 2016[8]).

\section{Figure 9. Demand for public transport services in the CAM}

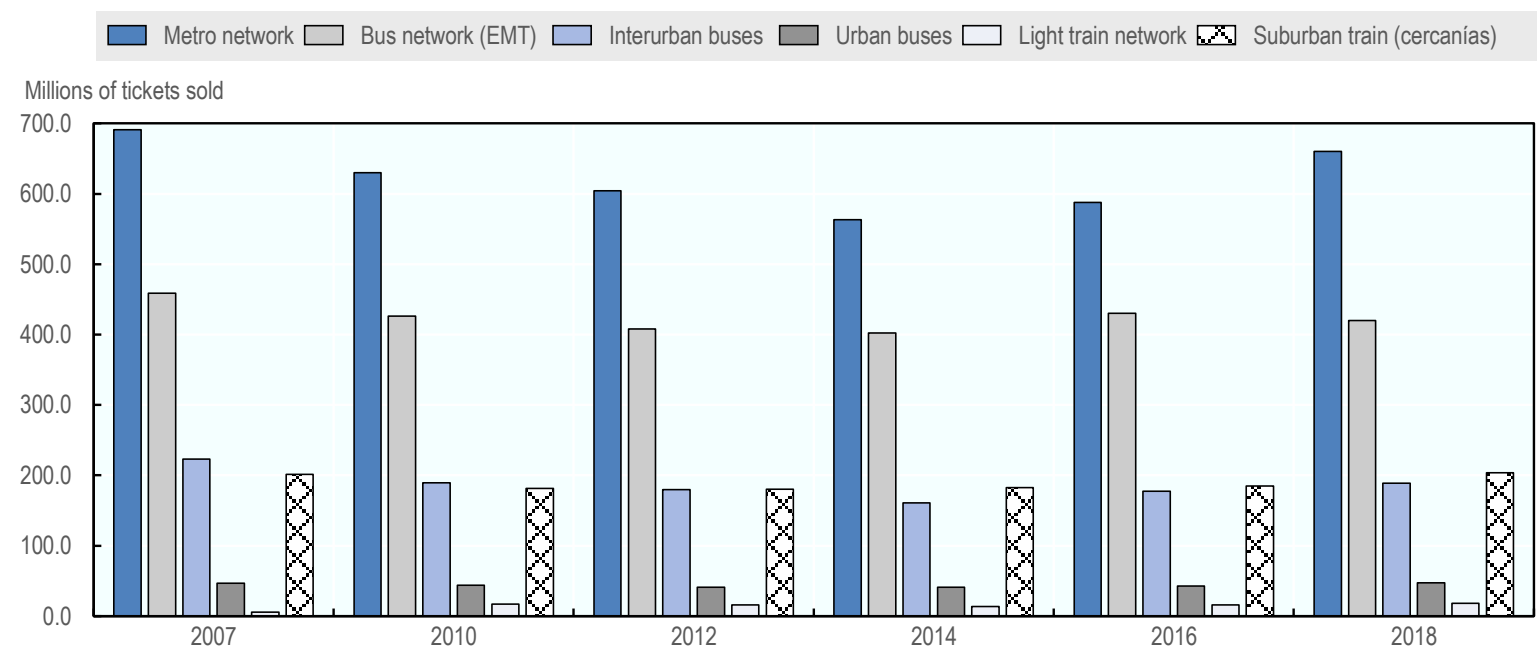

Source: Instituto de Estadística, Comunidad de Madrid: www.madrid.org/iestadis/fijas/estructu/general/anuario/ianucap09.htm 
As Table 6 shows, there are important differences in terms of mobility mode across the CAM. Half of the journeys take place within the municipality of Madrid alone. Walking is the main mode of transport in the interior of the municipalities in the rest of the region, but mobility between municipalities is mostly done by private car, which points to the dearth of public transport options across municipalities. In many cases, inter-municipal travel requires going into the city of Madrid first, even if that is not the final destination.

\section{Table 6. Distribution of mobility by spatial area in the CAM}

\begin{tabular}{|c|c|c|c|c|}
\hline Spatial area of mobility & Percentage & Walking (\%) & Public transport (\%) & Private vehicle (\%) \\
\hline Internal mobility in the Madrid municipality & 50.3 & 33.6 & 42.2 & 24.2 \\
\hline $\begin{array}{l}\text { Radial mobility between Madrid municipality and the } \\
\text { rest of the region }\end{array}$ & 15.6 & 0.6 & 49 & 50.4 \\
\hline $\begin{array}{l}\text { Internal mobility in municipalities in the rest of the } \\
\text { region }\end{array}$ & 24.8 & 56.5 & 9.8 & 33.7 \\
\hline $\begin{array}{l}\text { Mobility between municipalities in the rest of the } \\
\text { region }\end{array}$ & 9.3 & 2.0 & 28.6 & 69.4 \\
\hline Total mobility & 100 & 31.2 & 34 & 34.8 \\
\hline
\end{tabular}

Note: Data based on the last Household Mobility Survey (2004).

Source: (CRTM, 2013[15]).

\section{Most CAM residents are homeowners thus increasing demand for public transport}

Home ownership is a key determinant of people's mobility. In the CAM, approximately $63 \%$ of the housing stock is occupied by their owners. ${ }^{19}$ This has important implications for transport demand. Since people own the place where they live, they tend to move more for work and access to goods and services. In the CAM, the main mobility reason is going to work (Figure 10). When households opt for renting, they have more flexibility to change their residence depending on their work location and it is more likely they would choose to live close to their workplace. This is important because access to public transport has critical implications to access employment. The location of people's residence and the commuting time may facilitate or limit access to the job market. The problem in the CAM is that, according to officials interviewed for this paper, accessibility to transport is believed to have a bigger impact on rents than on buying a house. The lack of accessibility to public transport may have serious consequences on the socioeconomic situation of households that reside in places far away from job hubs. 
Figure 10. Most trips in the CAM are commutes to work

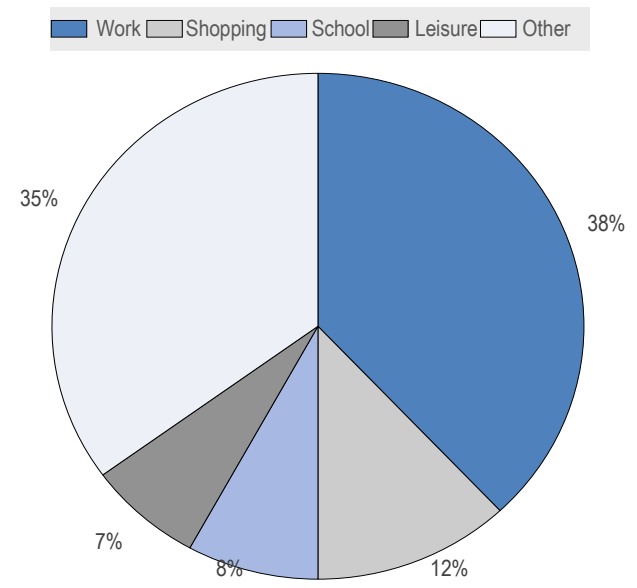

Source: (Velasco, 2016[8]).

In the CAM access to goods and urban services is becoming more difficult because population density is beginning to be higher in the periphery than in the City of Madrid. This means that connectivity across municipalities has to be ensured and that at some point the transport network may have to be redesigned to meet demand. Currently, going from one municipality to another may require going through the City of Madrid, which is not cost effective.

\section{Smart city and mobility solutions are used to promote sustainable transport}

Smart cities generally refer to communities leveraging (digital) technologies to boost citizens' well-being and deliver services in a more efficient, effective and sustainable manner. A key part of this concept is smart mobility that focuses on intermeshing digital technologies, vehicles and infrastructure for better traffic management, and more efficient mobility (ITF/OECD). The CRTM is promoting new mobility systems like car sharing, trip planning and bus priority services as a complement to public transport and to incentivise collaborative mobility. This initiative is in the framework of the smart city concept that the City of Madrid has adopted. Authorities in the municipality of Madrid are tackling traffic congestion, pollution and public services through a bottom-up approach using digital data. The focus is less on how and how much data is collected, and more on why gathering data to keep solutions citizen-centric and avoid having a technology dissociated from the people. ${ }^{20}$ For example, through the MoveUs project EMT is piloting the use of technology to improve the frequency and quality of the EMT bus service in Madrid as well as to provide better information to users on the best transport choice (Box 3).

\section{Box 3. Piloting smart city solutions to improve traffic in Madrid}

Like other European cities such as Genoa and Tampere, Madrid via EMT is piloting the MoveUs project, which aims to change users' mobility habits by offering intelligent and personalised travel information services, helping people to decide the best transport choice and providing meaningful feedback on the energy efficiencies obtained as a result. The initiative aims at citizens, tourists, public and private transit organisations, city authorities, local business, energy operators and ICT solution providers. There are three main objectives: i) to integrate mobility data from heterogeneous sources and deliver it in a coherent and useful way; ii) to provide green, multimodal, personalised, sustainable, safe and reliable 
services; and iii) provide business cases and incentives, recommendations for smart mobility services in urban environments. Some of the main achievements are: a cloud-based mobility management platform integrating different transport and traffic management components, which are able to collect heterogeneous data, and innovative user-centric city services aimed at assisting users' mobility and fostering behavioural changes towards sustainable transport modes.

Madrid MoveUs has two specific services: i) MoveUs App which is a smart mobility tool that provides green, multimodal, personalised, safe, private and reliable services which include: multimodal journey planner, energy efficiency clculation, and smart crossing service that allows pedestrians to activate the green light at pedestrians crossings unsing a mobile application; and ii) the Bus Priority Service which has been developed to give priority to delayed EMT buses in the selected crossings controlled by traffic lights from the urban traffic control system, in order to optimise travel time and frequency and therefore, the travel efficiency of the EMT bus service.

Source: (EMT, 2013[16]); www.moveus-project.eu/content/madrid and www.emtmadrid.es.

The CRTM is also promoting car sharing or Multi-User Vehicle Systems (MUVS). There are two operating companies Respiro and Bluemove that have an agreement with CRTM to allow discounts to the public transport users on these companies' rates. In addition, it allows Public Transport Card holders to use their vehicles. Since 2016, CRTM has undertaken three initiatives:

- Bicycle Routes Networks (RIB Plan), which is an inventory to identify potential actions to improve the cycling itineraries that enable favourable conditions on a basis of rapidity, accessibility and safety from or towards stations of the public transport network.

- Bicycle Parking Network (REB Plan), which consists in creating parking spaces for bikes in stops and stations of the public transport network. They are placed in points with good cyclist accessibility and favourable modal transfers.

- Use of the Public Transport Card (TTP) in the public bike sharing systems as in the case of the car sharing system. This possibility is also available in municipalities with a bike sharing programme with a compatible system in the Madrid region (e.g., G-Bici in the municipality of Getafe) (CRTM, 2016 $[5])$.

In the City of Madrid, the EMT operates the BiciMAD programme which is a public transport service $100 \%$ provided by electric bicycles. The system provides real-time information on available bicycles and stations. Due to a poor service provision by the private contractor, in 2006 EMT took over the service and after one year the availability of bikes increased 53\% and the daily users passed form 4000 to 12000 in 2017 . BiciMAD uses Information and Communication Technologies to improve the user experience allowing access to the service through several platforms: mobile phones, web, etc. The BiciMAD system has 2496 electric bicycles and 208 docking stations. ${ }^{21}$

The integration of public transport is enabled by the Centre for Integrated Public Transport Management (CITRAM), which is a public transport innovation and management centre. The CITRAM monitors the status of the public transport system to integrate information in real time about the infrastructure and services of all modes of transport that operate in the region. The objective is to improve mobility management and support decision-making with the data gathered. There are over 40 public and private operators in the CAM with a wide range of transport services and infrastructure. Through the CITRAM, the CRTM coordinates all those operators and establishes the conditions under which services must be provided. ${ }^{22}$

The new contactless card is a great opportunity to launch a Big Data initiative for the CAM's public transport sector. The pass records electronically all the trips by public transport users. This data could potentially be 
shared with universities and research institutions to explore how to improve the quality of public transport in the CAM.

\section{The city of Madrid is a lab for an innovative mobility regulation}

Policy-makers cannot ignore the transformation of means of transport that have been flourishing throughout the last $5-10$ years. Bicycles are a very well established means of transport in cities, and other less traditional vehicles, such as electric and non-electric kickboards and single-wheel vehicles (e.g. "segways"), are now more common in European cities. Although bicycles are part of included in the rules and norms that regulate transport, the other type of vehicles are not generally included.

The City of Madrid approved on 5 October 2018 a Local Regulation for Sustainable Mobility that aims to put urban mobility as the heart of local sustainable development, and to improve and simplify existing norms. The previous Mobility Regulation dated back to 2005 and has been modified on several occasions $(2007,2010,2012,2014$, and 2016). This new regulation was created in response to changes in the concept of "mobility" and the pressing needs to promote energy, economic and environmental sustainability, simplify norms, and promote a wider awareness among citizens. In particular, the new regulation aims at:

- Solving the regulatory dispersion in topics related to mobility

- Improving the technical nature of the previous regulation, by reducing its complexity and improving its structure to promote its content among citizens.

- Adapting regulations to the changes in the field of mobility.

- Regulating the coexistence of different uses of roads and urban spaces for circulation and parking, taking into account the environmental and economic dimensions

- Developing a regulatory tool that helps implement strategic urban plans: Air Quality and Climate Change Plan, Sustainable Urban Mobility Plan, Cyclist Master Plan and Municipal Disincentive Parking Plan, among others.

- Regulating new means of transport that are quickly emerging in the city (urban mobility devices, car-pooling, municipal cars, etc.).

The key innovative feature is that, for the first time in Spain, a regulation addresses the circulation of alternative means of transport. The latter is currently a legal grey area in the national "Law of Traffic, Circulation of Motor Vehicles and Road Safety". The approach to regulate this issue in the city of Madrid has been to make a clear distinction among the different types of new vehicles:

- Vehicles for Urban Mobility (electric kickboards, segways, etc.): the local regulation uses the classification of type of motor vehicles (A, B, C0, C1 and C2) established by the national General Traffic Directorate through the Norm 16/V-124. It then establishes that these types of vehicle have to circulate either on roads (where maximum speed is $30 \mathrm{~km} / \mathrm{h}$ ) or bicycle lanes. It also regulates the equipment (lights, braking device, whistle, etc.) that these vehicles have to incorporate to circulate legally.

- Rollerblades and kickboards, or similar vehicles, with no motor: will be able to circulate on sidewalks at a maximum speed of $5 \mathrm{~km} / \mathrm{h}$, and on all types of bicycle lanes.

- Skateboards: follow a similar regulation to rollerblades and kickboards, but its circulation will be forbidden in sidewalks or bike lanes that are too steep. This is to preserve safety since this kind of device has no brakes. For sport purposes, users will have to go to the specific areas authorised.

Lessons learned from this local regulation could be very illustrative for a national reform of traffic norms, or to replicate it in other cities. The monitoring and evaluation of the impact of this new regulation in the 
city of Madrid could indeed highlight, which is the most appropriate way to incorporate these vehicles to the streets.

\section{The 2009 financial crisis blocked transport projects in the CAM}

As a result of the 2009 global financial crisis and the Spanish economic crisis, national and local authorities faced budgetary restrictions that led to either the suspension of transport infrastructure projects or costcutting measures to their operations. Since 2011, the main cost-cutting measures applied in the CAM have included not only the dissolution of the Madrid Infraestructuras del Transporte (Mintra), the public body in charge of construction and management of transport infrastructures, but also reductions in the frequency of the metro services as demand was lower. It must be pointed out that the frequency of the metro service had returned to its pre-crisis levels before the outbreak of the COVID-19 pandemic. As for other transport projects, regional investments have already been stalled for several years. Moreover, the lack of investment in the railway network on expansion and improvements by the central government has had a negative effect on the CAM such as service delays.

The bursting of the housing bubble that was linked to the financial and economic crisis meant that reliance on private financing for new infrastructures was no longer a viable option. The costs of constructing and operating transport lines has become prohibited for local authorities, which now find themselves incurring significant debt. For instance, the municipality of Parla in the suburbs of Madrid was no longer able to pay the maintenance costs for its tramway, resulting in a two-day suspension of the service at the end of 2011. Parla, however, went ahead with the construction of the new tramway thanks to costly private financing measures that were implement in hopes that the new line would increase property values. In general, new transport projects rarely get off the ground as contract holders face many difficulties to secure support from banks in order to finance transport projects that are seen as no longer being profitable.

Another example is the case of the rail service linking the municipalities of Mósteles and Navalcarnero, which was abandoned in 2009 after more than a year of construction work. The concession agreement that was entered into for the financing, construction and operation of the $15 \mathrm{~km}$ line was suspended by the main contractor, whose organisation was banking upon significant population growth in the Navalcarnero area. The city had, in fact, intended to open up large swaths of land for urbanisation projects, with the objective of multiplying its population by five from 25000 to 125000 inhabitants. With the onset of the financial crisis, the regional authorities (CAM) never validated this development. Consequently, many residential and business units remain empty and the number of residents in the Navalcarnero area has remained unchanged. The contract holder had invested EUR 130 million of the EUR 360 million needed for the construction of the line, but it was unable to recuperate its investment. ${ }^{23}$

To improve the provision of public transport services to the CAM, since 2009 the CRTM has engaged in a Modernisation Plan of the Interurban and Urban buses. The Plan focuses on improving the quality of the service offered, accessibility, information to the user, comfort, security, limiting environmental impact and customer support. Progress is measured via quality indicators. The Plan aims to introduce new technological developments that should allow the implementation of contactless ticketing systems and wireless communication. In addition, the Plan aims to renew the bus fleet by reducing the average age of vehicles from 10-12 years to under 5 years, while improving the accessibility and homogenisation of the corporate image. Since 2009, the CRTM has renewed a fleet of 1500 buses that comply with European ecological directives. The average age of the bus fleet is now 4.29 years and $100 \%$ of the vehicles are accessible to people with different mobility needs. 


\section{From mobility to urban accessibility}

\section{Shifting from promoting mobility to urban accessibility in the CAM}

Based on the discussion above it may be argued that the Madrid Region has reached a level of development on transport and urban policies that enables a shift in its policy approach from focusing mainly on mobility to urban accessibility. There are social, economic and environmental reasons to support that shift. On the social front, it would facilitate people's access to goods and services that meet their needs with little need for mobility or through mobility options that have positive effects on health such as walking and cycling. From an economic point of view, it could make it easier for people to access jobs and for businesses to be closer to potential customers; it could also trigger new and more cost-effective methods of service delivery. On the environmental side, it would mean that mobility would have a less detrimental impact on climate and air quality as more sustainable transport options would reduce their carbon footprint.

Accessibility requires long-term planning, political commitment, technical and financial capacity, innovation in urban planning, a gradual evolution of transport policies, and a consolidated and integrated public transport network. As Table 7 shows, the Madrid Region already has some of the requirements that would underpin this transition, for example, the central agency for transport co-ordination, the regional and local mobility plans, the integrated transport system, the experimentation with alternative modes of transport and a participatory approach via the mobility tables. Regional and local authorities have been working for a long time on making the movement of people faster, easier, economic, and with the less possible impact to the environment using renewable energy. However, meeting economic, social and environmental goals in the CAM depends not only on easy access to jobs, goods and services but on how this is done in a more cost-effective manner for residents and transport authorities. If urban accessibility can be achieved in a way that meets people's needs, contributes to economic development and has no or little impact on the environment then the Madrid Region will be in a better position to ensure high levels of well-being, inclusiveness and sustainability. It could even be more resilient to natural, man-made and health emergencies in the future. Urban accessibility could be regarded as the ease with which residents reach destinations, access opportunities, and connect with one another (Rode et al., 2019 $\left.{ }_{[17]}\right)$. Accessing opportunities does not necessarily require commuting long distances.

Although the Madrid Region has a solid foundation enabling it to take transport and urban policy to the next level, there are some challenges that it needs to overcome (Table 7). Some of the most important ones are the lack of a regional development framework that coordinates policies and investment decisions under a common vision, the limited sources of funding for transport investment, and the fact that the regional transport strategy is not legally binding. The current socio-economic context may complicate adopting initiatives to foster urban accessibility such as transport infrastructure expansion. The preference and predominance for housing ownership will make necessary a full revision of the social and urban development strategy. However, regional and local authorities could include urban accessibility initiatives as part of the recovery package in response to the COVID-19 pandemic. Authorities could take the opportunities the current context offers such as the preference for active mobility, the short distances in central Madrid, and the emerging use of digital technologies and apply them to transport projects in the region. 
Table 7. Key points of the CAM's accessibility experience

\begin{tabular}{|c|c|}
\hline Strengths & Weaknesses \\
\hline $\begin{array}{l}\text { - A strategic sustainable mobility plan for the region and a specific } \\
\text { urban mobility plan for every municipality. } \\
\text { - An integrated public transport system for the region (administrative, } \\
\text { fare, modal and technological). } \\
\text { - A central agency for transport planning and coordination at regional } \\
\text { level with levels of technical capacity (CRTM). } \\
\text { - An updated regulatory framework that guides the use of new mobility } \\
\text { devices (i.e. e-bikes). } \\
\text { - A wide and technologically modern public transport network. } \\
\text { - The use of digital technologies for data gathering and traffic } \\
\text { management. } \\
\text { - The installation of Mobility Tables for discussion and stakeholder } \\
\text { participation in planning and decision-making. }\end{array}$ & $\begin{array}{l}\text { - The lack of a regional development strategy or plan. } \\
\text { - The strategic regional transport plan is not binding. } \\
\text { - There is minimal focus on accessibility. } \\
\text { - The limited coordination of housing, transport, land-use and } \\
\text { environmental policies at regional and municipal levels. } \\
\text { - Absence of a metropolitan body in charge of economic } \\
\text { development planning. } \\
\text { - Limited sources of funding and financing }\end{array}$ \\
\hline Opportunities & Threats \\
\hline $\begin{array}{l}\text { - Smart city initiatives that promote innovation for mobility. } \\
\text { - The use of digital technologies for transport services. } \\
\text { - The growing trend for active mobility (walking and cycling) and the } \\
\text { use of micro-mobility devices. } \\
\text { - The decrease in demand for drivers' licenses interpreted as a } \\
\text { preference for public transport and alternative ways of mobility. }\end{array}$ & $\begin{array}{l}\text { - The private car remains the main transport means. } \\
\text { - The administrative fragmentation of the metro area with a wide } \\
\text { diverse of municipalities with different levels of technical and } \\
\text { financial capacity. } \\
\text { - Housing trends as most residents are homeowners, thus limiting } \\
\text { mobility. } \\
\text { - The financial and economic crisis (the legacy of the 2008-09 } \\
\text { financial crisis and the current COVID-19 pandemic). }\end{array}$ \\
\hline
\end{tabular}

Source: Own elaboration.

Shifting from a purely mobility approach to a focus on urban accessibility is not an easy task. Planning the transport system should not be just about moving people from one point to another. The reason is that people use public transport to access jobs, goods and services and improve their levels of well-being. Thus, transport investment should be about facilitating that access. Accessibility is a combination of proximity and travel time and it is closely related to land use mix. Several indicators can be used to measure accessibility such as: population centrality, job accessibility by car or transit, distance to the city centre or central business district, and access to retail services. Planning for accessibility means shifting from a plan that focuses on transportation network efficiency to one that focuses on the network position and development potential of places in the urban network. The key questions CAM authorities would need to answer are how to develop places in the urban region that offer people and firms the means to reach more opportunities with less mobility; and how to design integrated land-use and transport strategies that support urban accessibility.

\section{Options to improve the efficiency of public transport in the CAM}

Although authorities in the CAM have made enormous progress in improving the performance of the public transport service, an important new priority in the current context is enhancing urban accessibility. For that, regional and local authorities will have to work together and individually in at least three policy areas: land use, transport policy and planning, and regional development policy that addresses social and economic issues. The reason is that focusing on the transport sector alone will not deliver good urban access. Figure 11 presents a summary of the main policy domains and actions that regional and local authorities may wish to consider to enhance urban accessibility. 
Figure 11. Policy priorities for enhancing urban accessibility in the Madrid Region

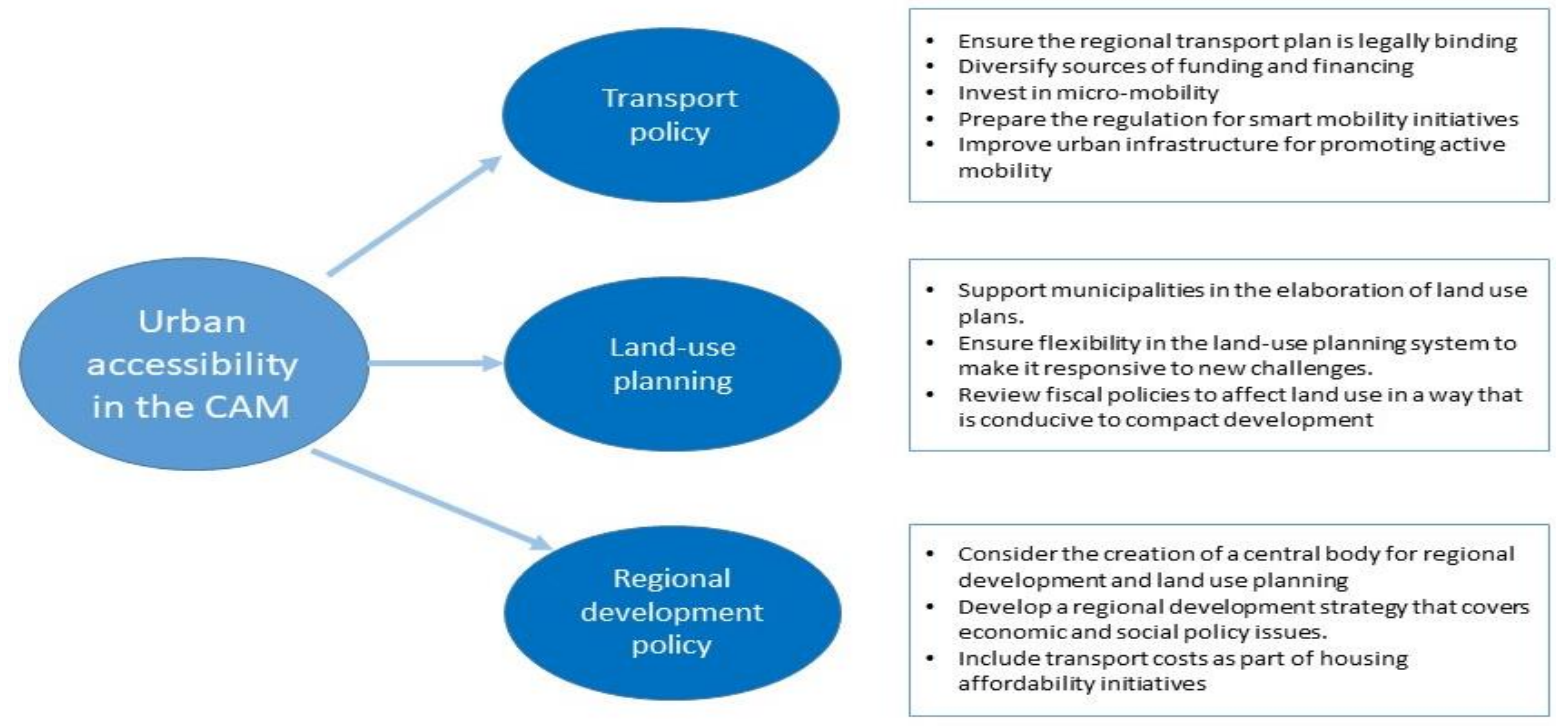

Source: Own elaboration

\section{On transport policy}

The CAM requires a legally binding regional strategic transport plan. Despite the existence of a regional mobility plan, it was not designed in collaboration with the municipalities and it is not enforceable. It may be argued that the CAM lacks a clear plan - at regional level - for that matter. The Strategic Sustainable Mobility Plan of the CAM (SSMP) presents a comprehensive view of the possibilities for investment on transport in the region and the relevance of a coordinated action with other policy sectors to enhance mobility. However, some municipalities in the region are not familiar with the SSMP and it has a more advisory character, which limits its impact. This could also avoid building expensive infrastructure that has little demand.

Transport investment in the CAM requires diversifying its sources of funding and financing. The problem is that since the regional government and Madrid city council are by far the main contributors to the financing of transport projects and that the service requires large subsidies, it may not be sustainable in the long term. This arrangement may be creating pressure as the region and the City of Madrid are mostly financing infrastructure for commuters from other municipalities where they pay taxes. The regional and local governments may need to rethink the current financing instruments and suggest several innovative funding programmes and instruments: taxation (land value capture instruments), public-private partnerships, and concessions could be some options to explore. Taxing car use to reflect its true costs (including externalities from driving such as carbon emissions, local air pollution, congestion and noise) would be a source of financing transport projects. Parking charges could also be a source of transport financing and they could also discourage driving in urban areas and have the associated benefit of avoiding using valuable urban space for parking. These instruments could be set out in a regional law for financing public transport to make it legally formal. Transport related fiscal policies need to supplement other policies, for example improvements to the public transport system and increased efforts at densification. Some commentators (Ruiz Montañez, 2014 $\left.{ }_{[7]}\right)$ argue that the country needs a Law on Financing Public Transport such as those in France, Germany, Italy and other EU countries. The reason is that municipalities have to commit growing amounts of resources on public transport because the shares of the central government have decreased. Moreover, the autonomous communities make little or no investments despite having delegated competencies on the domain. Another reason is that the current financial system does not take 
into account the specific needs of small cities or municipalities, which are very different from the large cities.

Anticipate risks and negative outcomes of micro-mobility. As the use of electric micro-mobility vehicles grows in Madrid (e.g. e-bikes and e-scooters), like in many cities around the world, the CRTM and municipal authorities need to plan carefully for the appropriate adoption of these alternative modes of transport. Issues could create disruptions to people's mobility, including: over-supply and indiscriminately parked devices clutter sidewalks; increase in energy use if charging and redistribution of shared devices is not made efficient; more crashes and injuries without proper infrastructure; displace transit, cycling, and walking trips; and high costs for low-income groups. The CRTM and local authorities could consider different options to make better use of these alternative means of transport. For example: CAM authorities could classify e-bikes and e-scooters as non-motor vehicles and clearly define maximum speeds for lowand moderate-speed devices; define the infrastructure that electric modes are permitted to use; design safe, inclusive infrastructure; integrate their fare with transit; and enforce safe use of cycling infrastructure. Equally important would be for the CRTM to integrate small electric modes into citywide mobility strategies and plans, and collect data for analysis and informed decision-making.

Prepare the ground for a wider adoption of digital technologies for better traffic management. At some point, the CAM will move on to adopt smart mobility initiatives of a larger scale. It will expand on the accumulated experience of the use of digital technologies for data generation on traffic flows and for the management of the bike-sharing system, for example. To move on to a full-fledged use of Intelligent Transport Systems, the CAM should include communication assets (vehicles, infrastructure and other devices), mobility data platforms and shared mobility services as taken together they have the potential to improve mobility outcomes and reduce negative externalities related to transport activity (ITF/OECD, $2020[18])$. As with the regulation of micro-mobility devices, the CAM could start reviewing and adapting the regulatory framework to enable innovation on smart mobility without hindering other desired societal outcomes such as equity, safety and efficiency. The CRTM could ensure that the regulatory framework is transparent, agile when needed, and clearly linked to other policy areas such as economic development, environmental protection, and urban development.

Improve the state of the streets to enable walking and cycling. The City of Madrid does not have a classification of the pedestrian network for the entire city that allows it to establish which streets need widening to facilitate pedestrians' mobility. In the central district of the city some pavements do not have the necessary width for pedestrians to move comfortably and in many cases there are obstacles on these sidewalks. Many areas will not meet the minimum road width needed in the new developments (CRTM, $\left.2013_{[3]}\right)$. The CRTM and the different municipal authorities may wish to design a strategy to finance the upgrading of the urban infrastructure, in particular pavements. A region-wide plan for urban regeneration may help to establish priorities and look for sources of financing. As a start, the CRTM and the municipalities may wish to shift to an approach where the streets are considered a means of transportation. Municipal government may wish to adopt specific programmes in their PMUS that focus on upgrading streets for cycling and walking.

\section{On land-use planning}

Support municipalities to prepare land use plans. Land use planning is place-based by definition, therefore municipalities should have a leading role in preparing and updating their land use plans based on their specific context and needs. However, some municipalities, in particular the smaller ones, may not always have the technical capacity or the necessary resources to engage in land use planning. Regional authorities could act on two fronts: issue policy guidelines with spatial implications to coordinate territorial development across the CAM, and provide technical support to municipalities that request it in the design or updating of their land use plans through collaboration agreements. Capacity building on land use planning is needed in particular when adopting flexible approaches to planning. 
Ensure flexibility in the land use planning system to adapt to changing context and priorities. As OECD $\left(2017_{[19]}\right)$ research has shown, it takes a long time to elaborate traditional statutory instruments of land use planning and even longer to have an impact. Thus, the planning system should have the instruments to respond to rapid changing needs. Flexible approaches to land use planning can be structured in different ways. For example, regional and municipal governments may establish specific zones in a community to temporary uses and experimentation. This could be of relevance when experimenting with new technologies for public transport such as automated cars in specific zones. With greater flexibility there would be fewer rules about how land is used and would allow authorities to judge every project on its own merit. However, it is important that this flexibility be delimited and not adopted everywhere, as historic centres such as those of the cities of Madrid and Alcalá de Henares need more stringent rules to protect them.

Review the fiscal framework to make it more compatible with and supportive of compact urban development. The national and regional authorities may wish to revisit tax policies to provide incentives on how to use and affect patterns of development. The reason is that taxes have varying effects on costs and benefits on land at different locations. For example, high fuel taxes make it more costly to use land in locations that necessitate a long commute and provide incentives for more compact and transit-oriented development. Authorities could explore the feasibility of taxing transport and in particular car use in a way that reflects its true costs, taking into consideration impacts such as noise, air pollution and congestion. The City of Madrid and other municipalities in the region could benefit from parking charges as they could discourage the use of cars and of valuable land for parking, particularly in historic centres. The national government may assess how feasible it would be to reflect the costs of car use via higher fuel taxes. This certainly will require coordination with other policies such as improvements in the public transport system, affordable housing policies for central areas, and increased efforts at densification.

\section{On regional development policy}

The CAM requires a comprehensive regional development plan that provides a coherent and coordinated approach to sectoral policies towards a common vision. The lack of regional planning is having a negative effect on urban development. As the economic, land use and transport patterns are evolving, authorities must plan at the level where the central city and the suburbs can be considered together. Regional planning may help make the most of scarce resources, build synergies across different policy sectors, and reduce the competition for resources between municipalities in the region. A regional development plan for the CAM would provide guidance to transport investment for the medium and long term, and transport planning should be given clarity on how it is contributing to regional socio-economic development goals. This is because regional planning would be a means of aggregating local plans, programmes and projects into a comprehensive regional development plan.

The CAM may need a metropolitan body for coordinating regional development and spatial planning, or giving this responsibility to the CRTM. Focusing on accessibility could help the transport system to catch up and keep pace with the evolving urban pattern and, in the current situation, shift from the prevalent radial structure (with the City of Madrid at the core) to a structure that accommodates better the increasing suburb-to-suburb traffic. The CAM has to overcome two problems here. One is that there is a poor connection between transport and spatial planning in the region. The second is that while the CRTM is responsible for transport planning at regional level only, each of the 179 municipalities has responsibility for spatial planning. To achieve a better integration of public transport and urban planning at a regional level may require revising the 2001 Land Act (ley de suelo). That revision may facilitate the transfer of responsibility of transport development to the actors that develop the land.

Transport costs should be considered part of strategies to ensure housing affordability. Providing adequate and affordable housing for certain groups is a key challenge in Spain (Pareja-Eastaway and SánchezMartínez, 2017[20]). Living in municipalities where housing is cheaper in comparison to central areas but 
where location requires a long commute for work, school or other services makes housing expensive. This is reflected in the growing quantity of people that have to travel across municipalities in the metro area for work, school or leisure. Thus, housing and transport planners in the CAM should consider integrated solutions to reduce housing costs, particularly in the city of Madrid, and enable spending on other basic necessities. A new conversation is needed among stakeholders from multiple sectors, but led by the CRTM, to better understand the connections, challenges and integrated solutions that are possible when housing, transport and the economy are considered together. Questions to initiate this new debate would be: how to connect transit and affordable housing? How to promote regional economic prosperity? How to partner to make solutions happen? How to connect transport provision in relation to housing and access to activities (i.e. employment, health, education and marketplaces) in the medium and long term? Transport accessibility should consider location (origin and destination), the opportunities that people want to access and the separation between people and those opportunities. Living in transit-oriented locations offer significant benefits for all households. 


\section{In conclusion - What lessons can be learned from the CAM's mobility initiatives?}

The experience of the Madrid Autonomous Community (CAM) in enhancing transport for better mobility and accessibility has key lessons for other cities facing critical transport challenges. Those lessons are:

- A metropolitan or regional body in charge of public transport is key to unlocking the potential of the public transport sector in a highly fragmented region or metropolitan area. Indeed, the creation of the CRTM has been key to coordinating public transport investments and, above all, the provision of services by managing the relationship with multiple contractors. The CRTM has the technical knowledge to support transport initiatives in member municipalities, which has led to one of the best public transport networks in Spain. It is clear that the incentives for the vast majority of municipalities to transfer their transport provision responsibilities to the CRTM has been both financial and technical. This technical knowledge, together with financial means, provides the transport body with the authority required to make decisions and formulate recommendations on transport planning. This has made cooperation operational.

- Creating a regional/metropolitan body for public transport requires technical capacity, political support and careful analysis of administrative and financial viability. Box 4 describes the process that led to the creation of the CRTM. One important element in the process was the political buy-in from the different municipalities of the CAM. Since the creation of the CRTM, the Madrid Region has seen an expansion of its public transport network, and small municipalities have gained access to the services that they would otherwise not have been able to provide due to their limited technical and administrative capacity. The CAM's experience suggests that the creation of a coordinating transport authority at the metropolitan level must be gradual, and that such a body should have functions and products no other authority can deliver. 


\section{Box 4. A roadmap for creating a metropolitan transport authority - the experience of Madrid's}

CRTM

- Conduct a feasibility study of the public transport authority design.

Ideally, the 'strongest' administration must launch this body, in collaboration with the rest of stakeholders participating. The structure should be based both on the current situation and on future functions the authority will administer. This should include:

- Assigned functions

- Institutional insertion and governance

- Organisation and staff

- Legal framework for the creation of the authority and its development

- Economic framework

- Discussion of the first model with the different administrations and proposal for implementation.

- Implementation.

- Development of the legal framework

- Information, communication and adaptation of the institutional framework

- Staff contracting and training (bringing in people from other administrations but also hiring new staff)

- Operation start up.

- First assignments: integrated service and mobility plan in the region. Definition of the integrated fare structure.

Source: (García Pastor, 2015[6])

- The introduction of an integrated fare structure facilitates coordination and standardisation. Fare integration contributes to reinforcing the authority of the transport agency, and is very popular with citizens. This has been a decisive instrument in maximising the economic and social performance of the resources employed in the operation of the transport network. The fare standardisation has simplified transport ticketing, thus facilitating and incentivising the use of public transport. This system makes pricing easier to understand as it replaced the kilometrebased and zonal fares. The CRTM is also working to increase ticketing options and introduce new technologies, such as the implementation of the contactless card, to facilitate the use of public transport. The fare system includes different kinds of pricing discounts for tickets as part of the government's policy to ensure that every resident is able to use the transport system and access jobs, goods and services.

- The adoption of an integrated transport system has contributed to the increase in efficiency of different modes by complementing one another. This is exemplified through the intercambiadores located in the strategic areas of Madrid. Having an integrated transport system has reduced unhealthy competition among the different transport providers in the different municipalities. Under the CRTM's supervision, the integrated transport system allows for the use of all modes of transport through a single system, enhancing their effectiveness and increasing cost efficiency. This has allowed the CAM, and in particular small municipalities, to enhance their 
capacity to deliver public transport services in a more reliable and safe manner. Developing an integrated transport system requires progressing gradually through coordination on a sound technical basis. Of key importance is the fact that integration of public transport has been physical (all transport modes operating as a single network) and managerial (planning coordinated by one single authority, the CRTM), but not operational as the CRTM is not a service provider.

- The interoperability and mix of transport types is one way to make city commuting more flexible. This is one of the main advantages of the CAM's transport system. This is being enhanced through digital technologies with a citizen-centric approach to improve mobility and traffic flow. Indeed, the use of digital technologies to optimise the performance of existing transport infrastructure is an opportunity to expand access to public services, contribute to economic growth and build more liveable environments. For example, Madrid's data platforms could enable municipalities in the region to gather data and make data-driven decisions, while digital connectivity allows citizens to access information, provide feedback and connect with government and transport authorities.

- Involving a wide range of stakeholders in the transport planning process is crucial. Indeed, citizens' participation on urban related issues seems to be gaining strength in the region. In the municipalities of Madrid, Alcobendas and Alcalá de Henares citizens play a more active role in the decision-making process. In Alcalá de Henares in particular, citizens' requests to clear the historic centre of traffic played a major part in the city council's decision to redesign the routes of the bus network.

- Keeping pace with the new and alternative modes of transport is needed for greater service efficiency. Like many other cities, the city of Madrid is seeing an increase in the use of micromobility means of transport (i.e. e-biking, skateboards and rollerblades). Updating regulation to promote and facilitate their use while ensuring the safety of users and pedestrians is part of the work to improve the performance of the transport system. This remains an unexplored issue in several cities that require consultation, experimentation and close monitoring. 


\section{References}

Cristóbal Álvarez, J. (n.d.), Transporte Público: Problemas, retos y soluciones, Consorcio Regional [10 de Transportes, Madrid, http://www.madrid.ccoo.es/62b29ecf8554a026ce5d5462ef9eb295000045.pdf (accessed on 4 October 2018).

CRTM (2016), Annual Report 2016, Consorcio Regional de Transportes de Madrid, Madrid, http://www.crtm.es (accessed on 19 October 2018).

CRTM (2013), Madrid, A World Reference - The Public Transport System in the Region of Madrid, Consorcio Regional de Transportes de Madrid, Madrid, https://www.crtm.es/media/157716/wreference-2013nov-web.pdf (accessed on 22 October 2018).

CRTM (2013), Plan Estratégico de Movilidad Sostenible de la Comunidad de Madrid 2013-2025, CRTM, Madrid, http://www.crtm.es/plan-estrategico-movilidad-sostenible (accessed on 2 October 2018).

EMT (2013), MoveUs - Concept, Goals and Partners, http://www.emtmadrid.es.

European Commission and UN-Habitat (2016), The State of European Cities 2016 Cities leading the way to a better future, European Commission, http://dx.doi.org/10.2776/770065.

Fernández Balaguer, S. (2017), BiciMAD, Madrid Bike Sharing System, EMT, Madrid, http://www.emtmadrid.es.

García Pastor, A. (2015), Integration of the Public Transport System in Madrid Region - Antonio..., Consorcio Regional de Transportes de Madrid, Madrid, https://www.slideshare.net/EMBARQNetwork/integration-of-the-public-transport-system-inmadrid-region (accessed on 1 October 2018).

Hrelja, R. (2015), "Integrating transport and land-use planning? How steering cultures in local authorities affect implementation of integrated public transport and land-use planning", Transportation Research Part A: Policy and Practice, Vol. 74, pp. 1-13, http://dx.doi.org/10.1016/j.tra.2015.01.003.

ITF/OECD (2020), Leveraging digital technology and data for human-centric smart cities: The case of smart mobility, http://www.oecd.org/termsandconditions. (accessed on 29 July 2020).

Ministerio de Fomento (2018), Estrategia Española de Movilidad Sostenible, Ministerio de Fomento, Madrid, https://www.miteco.gob.es/es/calidad-y-evaluacion-ambiental/participacionpublica/290409 eems definitiva tcm30-184109.pdf (accessed on 30 September 2020).

Municipality of Alcobendas (2018), Área de Seguridad Ciudadana, Movilidad y Protección Civil 2017 Memoria del Departmaento de Movilidad: Tráfico y Transportes, Departamento de Movilidad, Alcobendas, https://www.alcobendas.org/recursos/doc/Transporte trafico aparca/396813352 45201810340 .pdf (accessed on 17 October 2018). 
Municipality of Alcobendas (2010), Plan de Movilidad Urbana Sostenible de Alcobendas -

Resumen del Diagnóstico, https://www.alcobendas.org/recursos/doc/Documentales/Publicaciones municipales/47757700 8 18122012153921.pdf (accessed on 17 October 2018).

Municipality of Madrid (2014), Plan de movilidad Urbana Sostenible de la ciudad de Madrid, Ayuntamiento de Madrid, Madrid, https://www.madrid.es/UnidadesDescentralizadas/UDCMovilidadTransportes/MOVILIDAD/PMU S Madrid 2/PMUS\%20Madrid/Plan\%20de\%20Movilidad\%20de\%20Madrid\%20aprobacion\%20 final.pdf (accessed on 17 October 2018).

OECD (2020), City Policy Responses, OECD , Paris, https://read.oecd-

ilibrary.org/view/?ref=126 126769-yen45847kf\&title=Coronavirus-COVID-19-Cities-PolicyResponses.

OECD (2017), The Governance of Land Use in OECD Countries: Policy Analysis and Recommendations, OECD Publishing, Paris, https://dx.doi.org/10.1787/9789264268609-en.

OECD (2012), Compact City Policies: A Comparative Assessment, OECD Green Growth Studies, OECD Publishing, Paris, https://dx.doi.org/10.1787/9789264167865-en.

Pareja-Eastaway, M. and T. Sánchez-Martínez (2017), "More Social Housing? A Critical Analysis on Social Housing Provision in Spain", Critical Housing Analysis, Vol. 4/1, pp. 124-131, http://dx.doi.org/10.13060/23362839.2017.4.1.331.

Rode, P. et al. (2019), National Transport Policy and Cities: Key policy interventions to drive compact and connected urban growth, Coalition for Urban Transitions, London and Washington, http://www.coalitionforurbantransitions.org (accessed on 2 October 2020).

Ruiz Montañez, M. (2014), "La financiación del transporte urbano: un reto para las ciudades españolas del siglo XXI", Investigaciones Europeas de Dirección y Economía de la Empresa, Vol. 20/1, pp. 1-4, http://dx.doi.org/10.1016/j.iedee.2013.12.001.

Sobrino, N. (2016), The role of public transport in the Strategic Sustainable Mobility Plan of the Madrid Region, Vision 2025, Consorcio Regional de Transportes de Madrid, Madrid, https://www.polisnetwork.eu/publicdocuments/download/1996/document/sobrino-natalia---therole-of-public-transport-in-strategic-smp-of-madrid-region.pdf (accessed on 1 October 2018).

Straatemeier, T. (2008), "How to plan for regional accessibility?", Transport Policy, Vol. 15, pp. 127-137, http://dx.doi.org/10.1016/j.tranpol.2007.10.002.

Velasco, A. (2016), Integration of the Public Transport System in Madrid Region, Consorcio Regional de Transportes de Madrid, Madrid, http://ebsf2.eu/sites/default/files/8.1\%20EBSF 2\%20Madrid\%20Demo\%20Context.CRTM.pdf (accessed on 1 October 2018). 


\section{Notes}

${ }^{1}$ For further information see: Diario ABC Madrid https://www.abc.es/espana/madrid/abci-10-por-cientomadrilenos-dejara-transporte-publico-para-pasarse-coche-privado-crisis-covid-19-

$\underline{202006031305 \text { noticia.html }}$

2 See: Diario ABC Madrid https://www.abc.es/espana/madrid/abci-10-por-ciento-madrilenos-dejaratransporte-publico-para-pasarse-coche-privado-crisis-covid-19-202006031305 noticia.html

${ }^{3}$ For further information see: Cronica at https://cronicaglobal.elespanol.com/business/transporte-publicomadrid-barcelona-perdidas-covid-19 $355320 \quad 102 . h t m l$

4 For the city of Barcelona transport authority, the financial deficit amounts to EUR 200 million approximately. For further information see: Cronica at: https://cronicaglobal.elespanol.com/business/transporte-publico-madrid-barcelona-perdidas-covid19355320 102.html

5 For further information see: https://www.eleconomista.es/nacional/noticias/10582841/06/20/Lademanda-de-bicicletas-aumenta-un-260-durante-mayo-con-vistas-a-cambiar-el-modelo-de-transporteen-Espana.html

${ }^{6}$ For further information see: BiciMAD https://www.bicimad.com/

${ }^{7}$ It could also be referred to as the Madrid Region.

${ }^{8}$ With 17.8 municipalities per 100000 inhabitants, Spain is the $9^{\text {th }}$ most administratively fragmented country in the OECD. Country notes: Spain. Accessed at: http://www.oecd.org/regional/regionalpolicy/regional-outlook-2016-spain.pdf

${ }^{9}$ Around $59 \%$ of Spain's population lives in predominantly urban regions, making it the $6^{\text {th }}$ most urbanised country in the OECD. Country notes: Spain. Accessed at: http://www.oecd.org/regional/regionalpolicy/regional-outlook-2016-spain.pdf.

${ }^{10}$ For further information see: https://www.oecd.org/cfe/SPAIN-Regions-and-Cities-2018.pdf

${ }^{11}$ For further information see:

www.ine.es/prodyser/espa cifras/2017/files/assets/common/downloads/page0030.pdf

${ }^{12}$ For more information see Instituto Nacional de Estadística:

www.ine.es/ss/Satellite? L=es ES\&c=INESeccion $C \& p=1254735110672 \&$ pagename=Productos $Y$ Servici os\%2FPYSLayout\&param 1=PYSDetalleFichaSeccionUA\&param3 $=1259944561392 \&$ charset $=$ utf -

$\underline{8 \& \text { cid }=1259944593759}$

${ }^{13}$ For further information see: http://www.telemadrid.es/coronavirus-covid-19/Madrid-dispara-Covid-subirdesempleados-0-2228777105--20200505091615.html

14 For further information see: https://www.comunidad.madrid/noticias/2020/03/24/comunidad-madridrecibio-612-total-inversion-extranjera-espana-2019

${ }^{15}$ For further information see: https://www.mitma.gob.es/ 
${ }^{16}$ For further information see: Instituto de Estadística, Comunidad de Madrid, at http://www.madrid.org/iestadis/fijas/estructu/general/anuario/ianucap09.htm

${ }^{17}$ For further information see: Instituto de Estadísticas, Comunidad de Madrid, at http://www.madrid.org/iestadis/fijas/estructu/general/anuario/ianucap09.htm

${ }^{18}$ For further information see: https://www.abc.es/espana/madrid/abci-movilidad-madrid-tras-covid-19-2millones-menos-viajes-crisis-pero-10-por-ciento-mas-coche202006040128 noticia.html?ref=https\%3A\%2F\%2Fwww.google.com\%2Furl\%3Fsa\%3Dt

${ }^{19}$ Calculation based on the statistics of the CAM: www.madrid.org/iestadis/fijas/estructu/general/anuario/ianucap10.htm

${ }^{20}$ According to Urban HUB, the smart city concept is simply good urban planning that incorporates both advances in digital technology and new thinking in the age-old concepts of relationships, community, environmental sustainability, participatory democracy, good governance and transparency. For further information see: www.urban-hub.com/cities/fine-tuning-smart-in-madrid/

${ }^{21}$ For further information see: BiciMAD at: https://www.bicimad.com/index.php?s=que

22 For further information on the CITRAM see: www.crtm.es/media/148581/citram.pdf and www.madrid.org/cs/Satellite?c=CM InfPractica FA\&cid=1354338257673\&idTema=1142598721686\&lan guage $=$ es\&pagename $=$ ComunidadMadrid\%2FEstructura\&perfil $=1273044216036 \&$ pid $=1273078188154$

${ }^{23}$ For more information see: World Urban Campaign www.worldurbancampaign.org/iau-urban-transportchallenges-europe-context-financial-crisis 
More information: oecd.org/regional/

Follow us on Twitter:

y @OECD_local 